\title{
Concessions of Infrastructure in Latin America: Government-led Renegotiation
}

\author{
J.Luis Guasch \\ World Bank And University of California, San Diego \\ Jean-Jacques Laffont \\ University of Toulouse and University of Southern California \\ Stéphane Straub* \\ University of Edinburgh
}

March 17, 2006

\begin{abstract}
This paper analyzes government-led renegotiations in infrastructure concession contracts in Latin America, based on the same sample
\end{abstract}

\footnotetext{
*Corresponding author. School of Economics, University of Edinburgh, William Robertson Building, 50 George Square, Edinburgh EH8 9JY, UK. Email: stephane.straub@ed.ac.uk. We thank the editor Alvaro Escribano, two anonymous referees, Joshua Angrist, Emmanuelle Auriol, Jean-Paul Azam, Sandra Campo, Arnold Chassagnon, Denis Cogneau, Russell Davidson, Pierre Dubois, Antonio Estache, Vivien Foster, Guido Friebel, Jerry Hausman, Sylvie Lambert, Stéphane Luchini, Michel Lubrano, Brian Poi, Jozsef Sakovics and Fiona Scott-Morton, as well as seminar participants at University of Edinburgh, Paris LEA-DELTA, University of Toulouse, GREQAM-Marseille, the 2004 EC2 Econometrics of IO conference in Marseille, the 2005 workshop on Auctions and Public Service Procurement at Paris 1, EEA 2005 in Amsterdam and LACEA 2005 in Paris, for helpful comments. All remaining errors are ours. The findings, interpretations, and conclusions expressed in this paper are entirely those of the authors. They do not necessarily represent the views of the International Bank for Reconstruction and Development/World Bank and its affiliated organizations, or those of the Executive Directors of the World Bank or the governments they represent.
} 
used in Guasch, Laffont and Straub (2003) to examine firm-led renegotiations. After extending the theoretical framework to a multipleperiod context in which both Pareto improving and rent shifting renegotiations at the initiative of the government can occur, we develop an original instrumental variable strategy to address the issue of contract endogeneity and derive empirical results. While some of the main insights concerning the importance of having a regulator in place when awarding concessions and the fragility of price cap regulatory schemes are unchanged, significant differences arise with respect to the effect of investment and financing, as well as the corruption variables. We provide evidence that a good regulatory framework is especially important in contexts with weak governance and political opportunism.

\section{Introduction}

Contract renegotiation has long been an important topic in the theoretical contracting literature. ${ }^{1}$ However, despite the obvious relevance of this issue for practical contracting relationships, to date the empirical literature on the subject is extremely scant. A few papers have looked at how the potential cost of ex post renegotiations affects optimal contracting, be it the form of the contracts themselves, their degree of incompleteness, the way contractors are selected and their eventual bidding behavior. ${ }^{2}$ Recently, Gil (2005) looks at the determinants of contract renegotiation in the Spanish movie business, and the impact of those on the structure of the industry.

This paper analyzes the determinants of renegotiations at the initiative of the government in infrastructure concession contracts, using a Latin American data set from the World Bank, covering 307 concession projects in the sectors of transport and water, in five countries (Argentina, Brazil, Chile, Colombia and Mexico) between 1989 and 2000. Its empirical contribution is important in several ways. First, it is based on a unique dataset from several

\footnotetext{
${ }^{1}$ See for example, among many others, Dewatripont (1986), Hart and Tirole (1988) and Laffont and Tirole (1990) in the context of complete contracts, and Hart and Moore (1988), Green and Laffont (1992), Aghion, Dewatripont and Rey (1994) and Segal and Whinston (2002) when initial contracts are assumed to be incomplete.

${ }^{2}$ See Crocker and Reynolds (1993) on air force engine procurement, Bajari, McMillan and Tadelis (2003) on private sector building contracts, Chakravarty and MacLeod (2004) on form construction contracts, and Bajari, Houghton and Tadelis (2006) on highway paving contracts.
} 
Latin American countries that includes both detailed contract characteristics as well as more generic country institutional aspects and macroeconomic data, allowing to disentangle the role of contractual design, economic shocks and institutional quality in determining the performance of contracts.

Second, it analyzes the performance of infrastructure contracts in sectors that have a major impact on both social and economic development of the host countries. Therefore, to the extent that the results signal potential improvements in the form of contractual relationships, the policy implications may be crucial from a welfare point of view. Third, it is to our knowledge, the first study to look separately at renegotiation depending on which party initiates it.

There are additional good reasons that make Latin American data particularly appropriate for an empirical investigation on the determinants of concession contract renegotiation. Because the region was the pioneer in awarding concessions, by 2000 many countries had an established track record with this form of private sector involvement, allowing the construction of a suitable panel. ${ }^{3}$ Moreover, as mentioned above, the region has witnessed an unexpectedly high incidence of renegotiation. All this makes Latin America a perfect laboratory for this kind of study.

The present paper complements a previous study based on the same dataset that focused on the analysis of firm-led renegotiation (Guasch, Laffont and Straub, 2003, referred to hereinafter as GLS). There, we showed that more than half of these projects were renegotiated (162 out of 307) and very fast, on average 3.5 year after the signing of the contract. The paper built a model of renegotiation that included contract characteristics, regulatory and institutional environment, as well as external shocks, and conducted an empirical analysis that confirmed most of the predictions of the model and yielded interesting policy implications, especially with respect to the importance of having a regulatory body in place at the time of awarding a concession and of choosing the appropriate regulatory regime. We showed that price caps, which have been the dominant choice of policy makers in Latin America, suffer from a great fragility to shocks and trigger significant renegotiation. ${ }^{4}$

\footnotetext{
${ }^{3}$ See Harris (2003) and Guasch (2004).

${ }^{4}$ As a consequence, there is currently a growing pragmatic tendency to advocate the abandonment of price cap regulation, a synonym for the higher risk of renegotiation and higher cost of capital, and the return to an hybrid type of regulation, including some elements of rate of return. See for example Estache, Guasch and Trujillo (2003).
} 
Empirically, a number of differences with firm-led renegotiations are to be expected. One open question is the influence of price cap regulation. Firms' calls for renegotiation were the intuitive outcome when the cap appeared to be too restrictive. Here, we could expect a reverse effect, in the sense that governments would like to renegotiate caps that proved too generous and leave excessive profits to the firms (the opportunistic calls). However, it could also be the case that governments concerned about the continuity of service or the realization of planned investments would step in when firms are making losses, resulting in a similar effect of price cap on firm-led and government-led renegotiations. Another aspect of interest is the behavior of variables affecting the status quo of the parties in a renegotiation, in particular the financing variables, which effect should be the opposite as with firmled renegotiation. Finally, it is not clear how institutional quality variables should behave, as a number of channels involving the quality of the bureaucracy and the possibility of capture can be envisioned. Indeed, corruption can be expected to give rise to hidden and non-transparent renegotiations, ${ }^{5}$ or on the contrary to produce ex ante biased awards through direct adjudication or the manipulation of insider information, resulting in a situation in which concessionaire and government representatives share excessive rents and have little incentive to renegotiate.

From an econometric viewpoint, our analysis must address a number of issues. ${ }^{6}$ The starting point is the recognition of the potential endogeneity of most contract clauses. Indeed, we expect that a self-selection effect may affect the final characteristics of the projects to be undertaken and the clauses of the contracts according to governments' and concessionaires' specific characteristics, some of which will obviously not be observed. In other words, selfselection is most likely to arise because of the potential correlation between contractual and environmental explanatory variables and the error term as a consequence of omitted variables, in particular the above-mentioned unobserved characteristics of the parties and the projects. More specifically, these unobserved factors will likely be of two types: country-specific (political and institutional) and operator-specific.

We develop a set of two instruments that summarize, for each contractual dimension (e.g. price regulation, financing structure, guarantees) and

\footnotetext{
${ }^{5}$ E.g. the Mexican Northeast Railway concession or the generic case of highway franchising in Latin America, discussed in Engel, Fischer and Galetovic (2003).

${ }^{6}$ See Chiappori and Salanie (2003) for an overview of issues in the empirical contract literature.
} 
for each observation (each project in a given country and sector), the average prevalence, at the time the contract is signed, of the same contractual dimension for projects in the same sector in different countries, and in different sectors in different countries respectively.

To the extent that the correlation between the choice of price regulation for example, and unobserved variables boils down to country- and operatorspecific effects, the choice of price cap regulation will only be correlated across different countries (and different sectors) through some additional aspects that are independent of these specific effects, for example worldwide technology or policy trends, common across countries.

The second issue is related to the binary nature of our endogenous regressors. In binary outcomes model, a two-stage instrumental estimation is known to yield biased estimates, a problem that can be avoided performing maximum likelihood estimations. However, this proves intractable given the panel nature of our data and the fact that we deal with several endogenous variables simultaneously. Instead, we follow Angrist (1991), who argues that in a simple two-stage strategy the bias is likely to be negligible, and states moreover that this approach is acceptable as long as the focus is on causal effects rather than on the determination of structural parameters (Angrist, 2002). Finally, as robustness check, we estimate a linear probability model by two stage least squares and show that the results are preserved.

The results on both the importance of having a regulator and the fragility of price caps are unchanged with respect to firm-led renegotiation. On the other hand, consistently with the theoretical predictions, investment and financing variables have reversed effects, as does corruption. Moreover, we present additional evidence showing that the role of an experienced and independent regulator is especially important in contexts characterized by weak governance and high likelihood of political expropriation. This is certainly an important result, as it shows that strong and experienced regulators are likely to act as barriers against political opportunism, especially when they are present at early stages of concessions' lives.

Section 2 below presents the evidence concerning infrastructure concessions and government-led renegotiations in Latin America. Section 3 discusses the theoretical challenge posed by this type of renegotiation and spells out the model. Section 4 presents the data, explains the methodology in details and discusses the empirical results. Section 5 concludes. 


\section{Government-led Renegotiations: An Overview}

The 1990s witnessed a spectacular wave of private sector participation in infrastructure. Considering the four infrastructure sectors, transport, water, energy and telecommunications, US $\$ 754$ billion was invested between 1990 and 2001 in around 2,500 projects with private sector participation in developing countries. ${ }^{7}$ Of this, $48 \%$ was directed to Latin America and the Caribbean, where these investments were in their majority related to the sale or concessioning of existing assets. Due to political and sometimes constitutional and legal reasons making outright privatization difficult, concessions have been the salient choice for private sector participation. They have accounted for $67 \%$ of all projects worldwide, being moreover the almost exclusive form of private sector involvement in water and transport, as well as some energy projects. A concession provides its holder the right to operate a service for a limited period of time (usually 20 to 30 years), at the end of which all the assets revert back to the government. The concessionaire is responsible for any obligations specified in the contract in exchange for the right to the cash-flow of the users' payments.

However, by the early 2000s, a growing disenchantment with private sector involvement in general and concessions in particular has forced governments to slow down or stop the program and reform process in practically all countries in Latin America. Annual flows of investment are well below their 1997 peak. There are clearly doubts that stem from the frequent conflicts that arose in the past between contractual parties, with a large number of projects having been renegotiated or taken over by governments. Quite often, governments have behaved opportunistically, taking ex post regulatory actions to expropriate the available quasi-rents and "sunk" type investments.

Typical scenarios are a government or a mayor in the case of water concessions (mayors have exclusive jurisdiction on water operations) deciding in a unilateral fashion to cut tariffs or not to honor agreed tariff increases during a re-election campaign to secure popular support, or a new administration deciding not to honor the tariffs increase stated in the concession contract granted by the previous administrations.

Examples, to mention only a few, include recent popular unrest in Bolivia, which led in January 2005 to the cancellation of the La Paz and El Alto water

\footnotetext{
${ }^{7}$ See Harris (2003).
} 
concession, led by the French multinational Suez Lyonnaise des Eaux. As of 2005, most of the concessions awarded in Argentina prior to the 2001 crisis are still undergoing protracted renegotiation processes, despite the country's agreement to abide to international arbitration, under bilateral investment treaties signed by the government of Carlos Menem in the 1990s. ${ }^{8}$ The Limeira water concession in Brazil was denied tariffs adjustment supposed to be automatic according to the contract. The local mayor argued that the contract, signed by a previous administration, was unfair and compromised the municipality's long term interests. In 1995, a new local government took office and sought to limit previously agreed upon tariff increases in the Tucuman water and sanitation contract in Argentina. This finally led the concessionaire to abandon the concession in 1996. In the toll road concession in Pernambuco, Brazil, the regional government decided to cut the tariffs unilaterally shortly before elections.

In most cases, the social costs of such renegotiations are likely to be high. The knowledge by potential investors that the temptation exists to expropriate investments ex post may discourage investment in the first place or it might require an additional risk premium in the form of bigger tariffs or smaller transfer price to compensate for the increased cost of capital. ${ }^{9}$ Other potential costs include large scale service disruption, failure to meet coverage expansion targets and cost pass-through to users or taxpayers in excess of initial agreements. An extreme example is the Mexican toll road program, comprising 52 highways built under private concessions in the early 1990s, which was finally bailed out by the government in 1997 at an estimated cost of between US $\$ 7$ to 12 billion (1 to $1.7 \%$ of GDP). ${ }^{10}$

\section{Theory: Government-led Renegotiations}

From a theoretical point of view, government-led renegotiations represent a different challenge than firm-led ones. ${ }^{11}$ Indeed, if firms have private informa-

\footnotetext{
${ }^{8}$ See The Economist, March 17, 2005.

${ }^{9}$ In the water concession in the city of Buenos Aires, the regulator granted a tariff increase of $3.5 \%$ for each percentage point increase on the cost of capital (Guasch and Spiller, 1999).

${ }^{10}$ See Guasch (2004) for a detailed description of the Latin American experience with concessions and discussion on these and other cases.

${ }^{11} \mathrm{~A}$ longer version of the model summarized here, including detailed discussions of the assumptions, can be found in Guasch, Laffont and Straub, 2005.
} 
tion and anticipate opportunistic behavior by the government, for example because it is not able to commit not to renegotiate, they may want to hide their information to protect future rent. The resulting ratchet effect may give rise to extremely complex situations. ${ }^{12}$

While it is not our objective to develop and test a structural model, we intend to give some theoretical foundations to our empirical tests by extending the GLS framework to two or more periods, thus explicitly incorporating political cycle considerations in the analysis.

In GLS, we consider an ex ante regulatory contract between the government and a firm, under asymmetric information on the firm's cost, which the firm accepts or not before discovering its type. ${ }^{13}$ Therefore, because the participation constraint is only satisfied in expectation at the signing of the deal, ex post a high-cost firm is left with a negative utility and would like to renegotiate the contract. ${ }^{14}$ The government invests in a costly mechanism that ensures the enforcement of the contract with some probability $\pi(x)$, depending on the endogenous level of expenses $x$ incurred. The model is then enriched to include a number of characteristics of concession contracts, as well as the regulatory environment, exogenous economic shocks and the quality of institutions.

The probability of renegotiation is then given by the expression:

$$
\operatorname{Pr}(\text { renegotiation })=(1-\nu-\varepsilon)(1-\theta \pi(x)),
$$

where $1-\nu$ is the ex ante probability that the firm is of the high-cost type, $\varepsilon$ is a shortcut to model an exogenous shock on demand or on the firms' costs (through a devaluation or some similar macroeconomic shock), and $\theta$ is a shift parameter capturing the level of quality of institutions, with $\theta$ closer to 1 corresponding to better institutions (more efficient bureaucracy, less corruption).

The following Figure 1. summarizes the structure and outcome of this model.

\footnotetext{
${ }^{12}$ See for example Laffont and Tirole, 1993.

${ }^{13}$ Several extensions are presented in Guasch, Laffont and Straub, 2006.

${ }^{14}$ See Laffont and Martimort, 2002, chapter 2. Note that this extends to the case in which the firm is protected by limited liability, for example because it must be able to repay the amount privately borrowed to finance the investment. Then, a high-cost firm still intends to renegotiate if the expected utility from doing so exceeds its utility under the initial contract.
} 


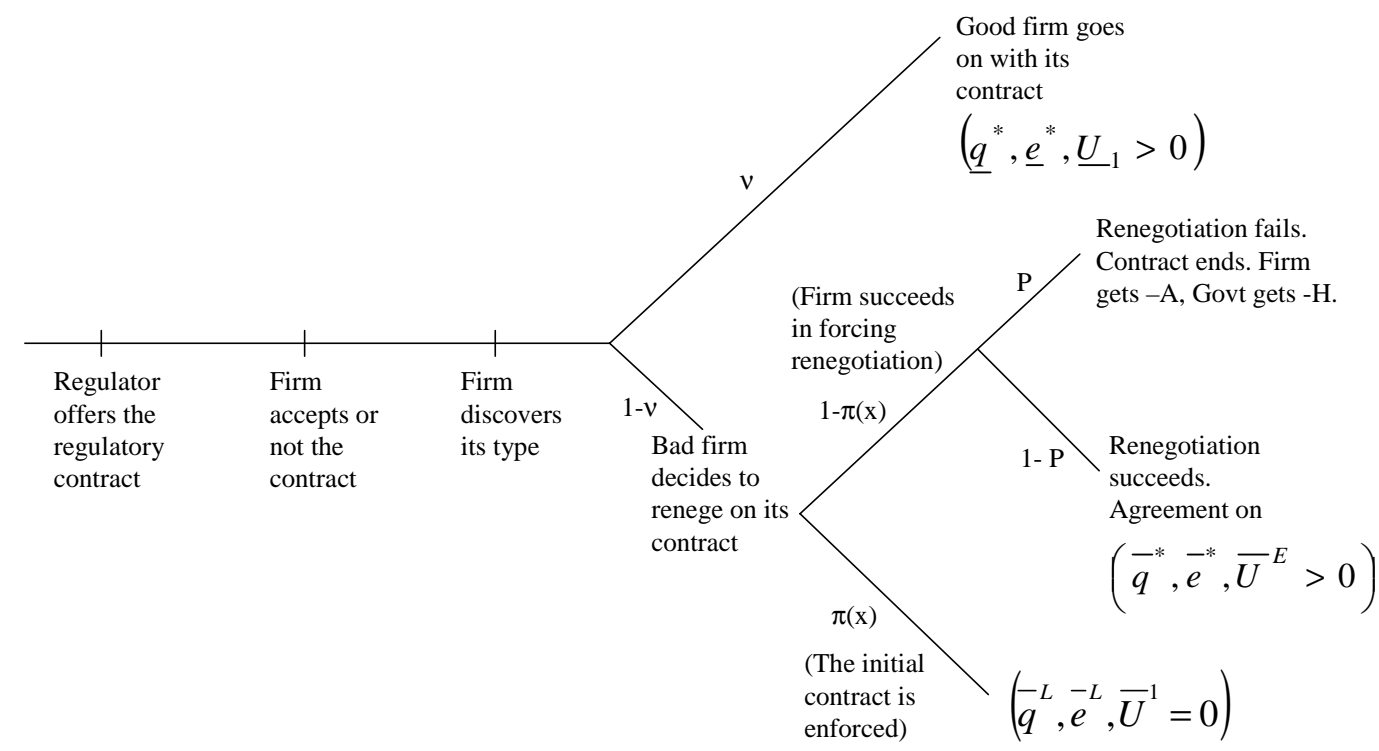

Figure 1: GLS theoretical framework

\subsection{Political Cycle}

To account for the possibility that at some point during the life of the project, the regulatory body may propose to the firm a renegotiation of the initial contract, we now explicitly introduce political cycle considerations.

Consider that the contract described above is signed for two periods. ${ }^{15}$ At the beginning of the second period (time $t=2$ ), elections take place and the incumbent government is reelected with exogenous probability $q$. With probability $1-q$, a new government is elected and then remains in power throughout the second period. ${ }^{16}$

Moreover, we assume that the initial government has the ability to engage in long term contracting that goes beyond its own term in power. We also assume it can commit itself to its policy (commit not to renegotiate), so

\footnotetext{
${ }^{15}$ As will become clear, this could be extended to 3 or more periods without changes. Note that in our sample more than $97 \%$ of the contracts are signed for between 20 and 30 years.

${ }^{16}$ The reason to consider the probability of a political change as exogenous is that regulatory issues are unlikely to be pivotal in shaping the outcome of elections. This assumption is introduced for example by Besley and Coate (2003) in the context of US data.
} 
that if it remains in power, no government-led renegotiation offer is made. However, when a change of majority occurs, the new government has the ability to renegotiate, with the initial contract representing the status quo utility level of the firm. Thus, the firm may refuse the new contract it is offered and carry on with the initial one. ${ }^{17}$

Additionally, we assume that with a small probability $\mu$, the newly elected government does not respect its legal obligations and it reneges on the outstanding contract, in effect expropriating the firm's rent. In this context, it is intuitive to think about the probability of expropriation as a shortcut to the country's level of political risk, which is known in expectation by the investing firm and guides its decision to apply for the concession ex ante. It therefore makes sense to keep it exogenous, as it is likely to depend on factors lying outside the scope of a given concession. ${ }^{18}$

\subsection{Pareto Improving Renegotiation}

In second period, a newly elected government (probability $1-q$ ) makes a takeit-or-leave-it renegotiation offer to the firm. If the firm accepts the offer, the contract is modified accordingly. If it rejects it, the original contract remains unaltered.

Given the possibility of political change, the initial government does not alter the contract it offers to the firm at time $t=1$, which is still characterized by the following menu:

$$
C=\left\{\left(\bar{q}^{L} ; \bar{e}^{L} ; \bar{U}^{1}=0\right) ;\left(\underline{q}^{E}=\underline{q}^{*} ; \underline{e}^{E}=\underline{e}^{*} ; \underline{U}^{1}=\Phi\left(\bar{e}^{L}\right)\right)\right\} .
$$

This follows straightforwardly from the fact that this government is not able to renegotiate the contract if it stays in power in the second period, nor is it able to shift the allocation of the rent across time. ${ }^{19}$

\footnotetext{
${ }^{17}$ See Aubert and Laffont (2002) for a justification of this assumption.

${ }^{18}$ While political risk assessment is widely used by firms investing in developing countries, some extreme and unforeseeable cases of commitment breakdown seem to be driven more by governments' inability to manage shocks, as the following quote from Harris (2003) suggests: "For their part, some investors over-estimated the ability of governments to manage the reform process and hence honor their tariff, and other, commitments. In some cases, such as in Indonesia and Argentina, this extended to judgments about the ability of the government to sustain stable macroeconomic policies."

${ }^{19}$ This would only matter if the government were composed of stake-holders of the firm, so it would retain some benefit from the firm's rent even after leaving power. In this case,
} 
The key issue here is to determine whether the fact that a new government offers to renegotiate the original contract with probability $1-q$ will induce any strategic behavior from the firm in the first place. In other word, we need to determine whether they will be any ratchet effect.

This question boils down to the problem of whether the good type will have an interest in mimicing the bad type at $t=1$ in order to secure a better deal at $t=2$. Indeed, given the original contract, at $t=2$ the new government will only offer renegotiation to the bad type, proposing to raise the level of production $\left(\bar{q}^{L}\right)$ to the first best level $\bar{q}^{*}$, while maintaining its rent to the previous level $\left(\bar{U}^{1}=0\right)$. There is no room for renegotiation with the good type, as it is already producing the first best level $\underline{q}^{*}$ and would reject any proposal reducing its rent.

The analysis in the present case is greatly simplified by observing that the original contract is signed before the firm actually learns its type. Moreover, just after the initial agreement, the bad type firm actually intends to renegotiate its contract. Thus, the only way for a good firm to mimic a bad one would be to ask for a renegotiation at $t=1$. We have assumed that in the original model without political change, the good firm is worse off if mimicing the bad firm and renegotiating. We refer the reader to Guasch, Laffont and Straub (2005) for the derivation of the modified condition, which is the equivalent (in a two period framework) of the condition spelled out for the general model in footnote 13 of GLS, and which we again assume is satisfied.

Therefore, Pareto improving renegotiation only occurs for the bad type firm, with the result that the production level is raised to the first-best level and the rent stays at its previous level of zero.

\subsection{Rent Shifting Renegotiation}

Consider now that with probability $\mu$, the newly elected government does not stand by its obligation to respect the status quo utility of the firm and expropriates its rent, as in the introductory example of an incoming administration deciding not to honor tariff adjustment committed by its predecessor. Two additional instances of renegotiation now occur. First, with probability $(1-q) \mu$, the government reneges on the good firm's contract and offers a new contract $\left(\underline{q}^{*} ; \underline{e}^{*} ; 0\right)$. Second, when a firm-led renegotiation has succeeded

it may want to distort the original contract to modify the posterior renegotiation game between the firm and its successor (Aubert and Laffont, 2002). 
in period 1, the bad firm enjoys a contract giving it a rent $\bar{U}^{E}$. Again, with probability $(1-q) \mu$, the government calls for a renegotiation and makes a take-it-or-leave-it offer involving a contract $\left(\bar{q}^{*} ; \bar{e}^{*} ; 0\right)$.

It is easy to see that the separating condition spelled above is not modified substantially. indeed, the left hand side changes as the utility that accrues to a good firm choosing the good contract at $t=1$ is now brought down to 0 with probability $(1-q) \mu$ at $t=2$. If $\mu$ is small enough, this inequality is still verified. ${ }^{20}$

\subsection{Probability of Government-led Renegotiations}

Considering that the good type will not want to cheat, we show in Figure 2 below the tree of actions and the eventual occurrence of renegotiation.

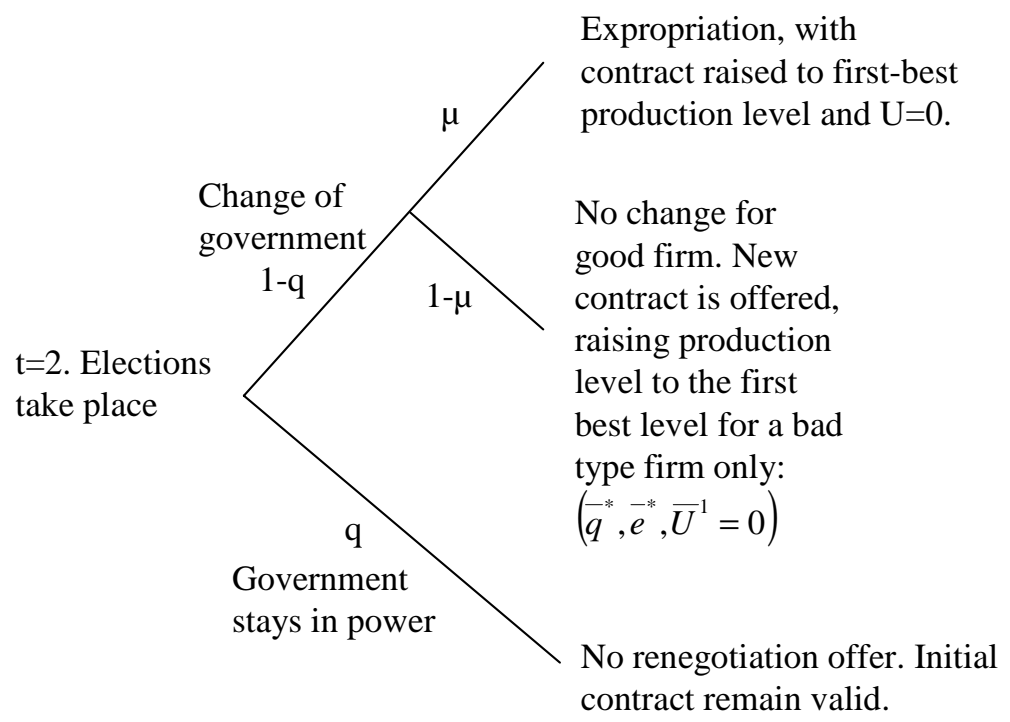

Figure 2

Conditional on a political change, the probability of renegotiation at the initiative of the government is given by the sum of the probabilities to have a Pareto improving renegotiation (contract with a bad type firm that was

\footnotetext{
${ }^{20}$ See Guasch, Laffont and Straub (2005).
} 
successfully enforced $\left.(1-\nu-\varepsilon) \theta \pi\left(x^{L}\right)(1-q)\right)$ and a rent-shifting renegotiation: contract with a good firm, probability $(\nu(1-q) \mu)$, as well as renegotiated contract with a bad type firm $\left((1-\nu-\varepsilon)\left(1-\theta \pi\left(x^{L}\right)\right)(1-P)(1-q) \mu\right)$. This yields:

$$
\begin{aligned}
& \operatorname{Pr}(\text { Govt-led renegotiation })= \\
& (1-q)[\mu-(1-\nu-\varepsilon) P \mu+(1-\nu-\varepsilon)(1-(1-P) \mu) \theta \pi(x)] .
\end{aligned}
$$

\subsection{Link with Empirical Analysis}

Before introducing the empirical work, it is useful to summarize the lessons of the theoretical model and to make clear how they inform the data analysis.

Table 1: Predictions of the model and empirical proxies

\begin{tabular}{|l|l|c|c|}
\hline \multicolumn{1}{|c|}{$\begin{array}{c}\text { Variables of the } \\
\text { theoretical model }\end{array}$} & \multicolumn{1}{|c|}{ Variables of the empirical model } & Expected effect & $\begin{array}{c}\text { Comparison } \\
\text { with firm-led } \\
\text { renegotiation }\end{array}$ \\
\hline $\begin{array}{l}\text { Probability of } \\
\text { renegotiation }\end{array}$ & $\begin{array}{l}\text { Renegotiation initiated by the government: Dummy variable indicating } \\
\text { whether there was or not a renegotiation of the concession contract at the } \\
\text { initiative of the government. }\end{array}$ & left-hand variable & ambiguous \\
\hline $\begin{array}{l}\text { The pre-contract } \\
\text { asymmetry of } \\
\text { information } \\
\text { determines the power } \\
\text { of incentives }\end{array}$ & Price cap: Dummy variable taken as a proxy for the power of incentives. & same \\
\hline Sunk cost F & $\begin{array}{l}\text { Investment requirements: Dummy variable indicating whether there are or } \\
\text { not investment requirements as part of the concession contract, investment } \\
\text { being considered to be mainly sunk. }\end{array}$ & ambiguous & reversed \\
\hline Private financing K & $\begin{array}{l}\text { Private financing: Dummy variable indicating whether the project is } \\
\text { funded entirely through private funds, excluding any public investment. }\end{array}$ & ambiguous & reversed \\
\hline Shocks $\varepsilon$ & $\begin{array}{l}\text { Growth / Exchange rate shocks: internal or external macroeconomic shocks } \\
\text { that impact either cost or demand of the firms. }\end{array}$ & same \\
\hline Institutional quality $\theta$ & $\begin{array}{l}\text { Indices of corruption / rule of law / bureaucratic quality: standard } \\
\text { perception indices taken as proxies of institutional quality }\end{array}$ & + & reversed \\
\hline $\begin{array}{l}\text { Elections/political } \\
\text { changes 1-q }\end{array}$ & $\begin{array}{l}\text { Elections: Changes of the political majority are considered to trigger offer } \\
\text { to renegotiate from the new government. } \\
\text { Existence of regulator: Dummy variable indicating whether there was a } \\
\text { regulator or no at the time the contract was signed. The existence of a } \\
\text { regulator might correspond to a lower ability to renegotiate by new } \\
\text { government. }\end{array}$ & + & same \\
\hline
\end{tabular}

Given the expression for $\pi(x)$, and the comparative statics already discussed in GLS, it is possible to derive from the model a set of predictions for the sign of the effects of different variables on the probability of governmentled renegotiation. One key implication is that any variable of the model affecting the enforcement probability $\pi(x)$, either directly, like institutional variables $(\theta)$, or indirectly, like the financing aspects $(K$ and $F$ ) that define 
the statu quo of the parties, will have opposite effect on the probability of government-led versus firm-led renegotiation. On the other hand, the effects of price regulation, elections, shocks or of the existence of a regulator, appear to be unchanged. Assessing the relevance of this prediction will be one objective of the empirical analysis.

However, as explained in the introduction, the empirical analysis intends to go beyond the model developed above and it will more generally aim at testing the effect of a number of contractual and environmental variables on the likelihood of government-led renegotiation calls, with a special focus on political variables and aspects related to the quality and efficiency of government institutions. Table 1 summarizes the predictions for a number of variables included in the model.

\section{Empirical Evidence}

\subsection{The Data}

We use an original data set, developed by the World Bank, which describes the characteristics of nearly 1,000 concessions awarded in Latin American and Caribbean countries from 1982 to $2000 .{ }^{21}$ As in GLS, and to keep results strictly comparable, we again focus on water and transport concessions in five countries (Argentina, Brazil, Chile, Colombia and Mexico), between 1989 and 2000. We have information on the general details of the projects (sector, activity, year of award, award criteria, size and duration of the concession), on the institutional and regulatory context, the type of regulatory framework put in place (price cap or rate of return), as well as the evolution of the main economic variables (growth, exchange rate, inflation) and the timing of national and local elections. Tables A1 in the Appendix presents the full list and definitions of variables used in the analysis below and gives summary statistics, while Table A2 shows the distribution by types (e.g. price cap vs. rate of return regulation, minimum income guarantee vs. no guarantee, etc.) of the renegotiated and non-renegotiated concessions, looking first at all renegotiations and then only at government-led renegotiations.

Looking at the incidence of the different types of renegotiations (led by firms, the government or both), 162 out of 307 projects were renegotiated, with 53 firms' calls, 15 joint calls and 94 governments' call. These

\footnotetext{
${ }^{21}$ See GLS (2003) and Guasch (2004) for additional details on the data set.
} 
government-led renegotiations appear to be concentrated in Brazil (36), Mexico (57) and Colombia (1). The Brazilian wave of renegotiation occurred between 1997 and 2000, with a peak in 1999 (24). In Mexico, it was between 1993 and 1998, with more than 10 renegotiations in each year from 1993 to 1996, and a peak of 19 in 1995 (see Table 2).

Table 2: Government-led renegotiations by country, year and sector

\begin{tabular}{|lccccccccc|}
\hline & 1993 & 1994 & 1995 & 1996 & 1997 & 1998 & 1999 & 2000 & Total \\
\hline Brazil & & & & & $0 / 1$ & $0 / 5$ & $15 / 9$ & $0 / 6$ & $15 / 21$ \\
Colombia & & & & & & & $1 / 0$ & & $1 / 0$ \\
Mexico & $5 / 5$ & $8 / 5$ & $3 / 16$ & $1 / 10$ & $2 / 0$ & $0 / 2$ & & & $19 / 38$ \\
\hline
\end{tabular}

(Renegotiations in the transport sector/ Renegotiations in the water sector)

This observed concentration in 2 countries and within well-defined time periods raises the potential caveat that political and institutional variables may exhibit little variance in actual renegotiation cases. However, we expect the significance of these variables to stem from the variance between countries and time periods with and without renegotiations. Why did electoral dates generate renegotiations in Mexico and Brazil and not in Chile or in Argentina? What conjunction of contractual clauses, economic and political events prevented political changes in Brazil before 1999 to end up in a wave of government-led renegotiation calls? We still expect political variables in our sample to provide an important part of the answer.

As for the sector allocation, renegotiated transport projects are exclusively road projects (15 in Brazil, 1 in Colombia and 19 in Mexico). Renegotiated water projects are more evenly distributed: Of the 21 Brazilian cases, 3 were in potable water, 7 in sewer, and 11 in composite projects, while of the 38 Mexican cases, 6 were in potable water, 29 in sewer, and 3 in composite projects.

\subsection{Timing of Renegotiations}

To contrast the relevance of our theoretical approach, we start by analyzing the timing of the different types of renegotiation, in particular with respect to election deadlines. Figure 3 shows the number of governmentand concessionaire-led renegotiations, disaggregating them by looking at 
how many elections took place during the life of the project. As is apparent, government-led renegotiations tend to be strongly concentrated after the first election ( $79 \%$ of the total), while concessionaire-led ones are more evenly distributed and take place almost with equal frequency after 0,1 , or 2 elections. ${ }^{22}$

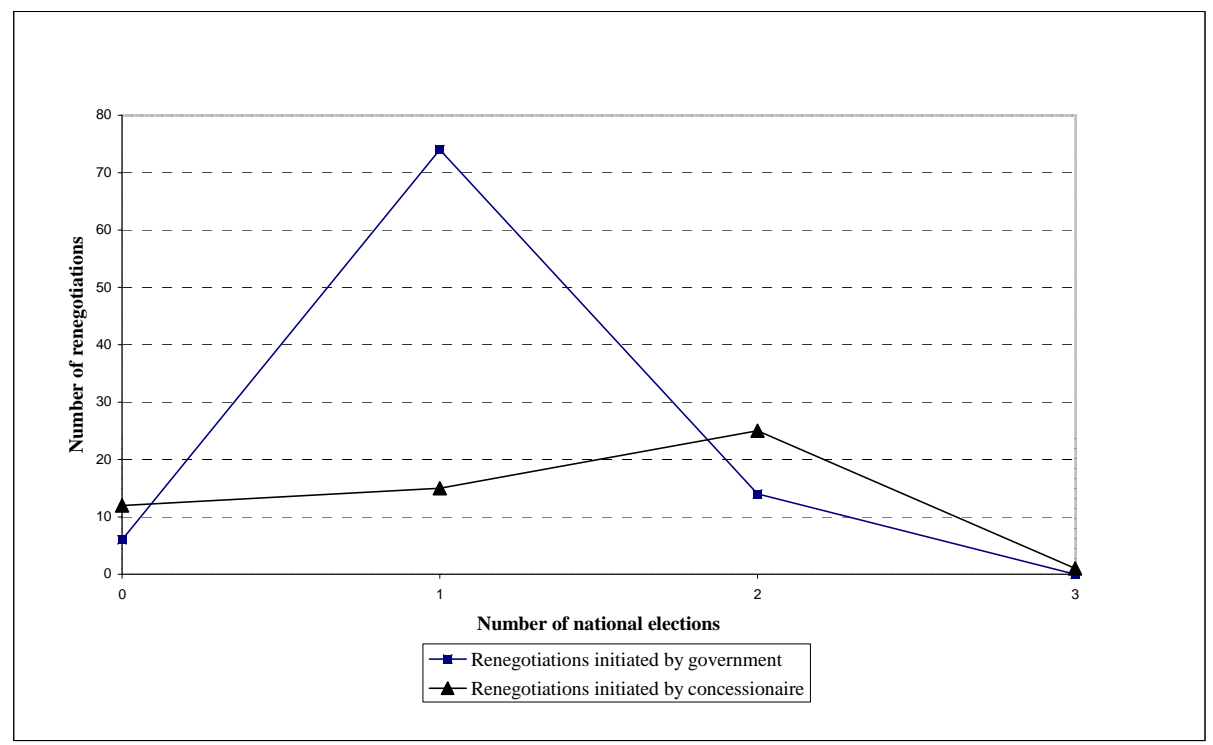

Figure 3

We confirm these stylized facts in the probit analysis. Indeed, results not shown here indicate that a lagged dummy for the first election is positive and significant at the $5 \%$ level on the probability of government-led renegotiation, with a marginal effect slightly above 10\%, while it is negative and not significant for firm-led renegotiation. Overall, this gives a picture consistent with our model assumption, namely that concessionaire-led renegotiations tend to occur mainly for contractual reasons or in response to adverse unexpected shocks, while government-led renegotiations are generally politically motivated and are likely to follow elections.

\footnotetext{
${ }^{22}$ Note that a representation of sample hazard rates, showing these figures as percentages of outstanding concessions, gives similar results.
} 


\subsection{Methodology}

We perform random probit estimations, using as dependent variable the dummy indicating, for each project $i$ in country $n$, whether there is a renegotiation initiated by the government at time $t$, where $t$ varies between 1989 and $2000 .^{23}$ The probit model is given by:

$$
y_{\text {int }}=1\left[y_{i n t}^{*}=x_{i} \alpha_{1}+\alpha_{3} z_{i n t}+E_{n t} \alpha_{3}+e_{i n t}<0\right],
$$

where 1[.] is the indicator function taking value 1 whenever the statement in brackets is true, and 0 otherwise; $y_{\text {int }}$ is the binary variable indicating whether concession $i$, in country $n$, at time $t$, was renegotiated or not at the initiative of the government; $x_{i}$ is a vector of time invariant characteristics of the concession contracts; $z_{i n t}$ is the number of years, since the award of concession $i$, in country $n ; E_{n t}$ is a vector of environmental characteristics (macroeconomic indicators, elections and institutional indices); $e_{i n t}$ is the error term; and $\alpha_{1}, \alpha_{2}$, and $\alpha_{3}$ are the vectors of parameters corresponding to $x_{i}, z_{i n t}$ and $E_{n t}$ respectively.

\subsection{Endogeneity}

As already discussed in GLS, the use of contractual aspects as explanatory variables raises the question of their potential endogeneity. Indeed, we expect a self-selection effect, with governments and concessionaires altering the final characteristics of the projects to be undertaken and the clauses of the contracts according to the projects' as well as their own characteristics, which may sometimes be unobserved.

The first issue in a such a context, is the choice of suitable instruments. We start by observing that in an estimation of the probability of renegotiation using environmental and contractual explanatory variables, the potential source of self-selection-related endogeneity of the latter lies in the potential correlation between them and the error term as a consequence of omitted variables, in particular unobserved characteristics of the parties and the projects. More specifically, these unobserved factors will likely be of two types: country-specific (political and institutional, like the degree of political capture of specific regulatory institutions, the "tradition" to expropriate

\footnotetext{
${ }^{23}$ Additionally, some robustness checks use as dependent variable the dummy variable indicating whether there is a renegotiation initiated by the government or by both parties.
} 
investments in certain sectors, or the political culture leading to different degrees of popular interference with state-operators interactions) and operatorspecific (like the strategic skills of the firm in renegotiating contract clauses, or the propensity to incur in strategic underbidding and renegotiate later on).

To address this, we develop for each contract clause a set of two instruments that are correlated with the variables to be instrumented (regulation, structure of financing, guarantees, etc.), while not being correlated with the unobserved factors mentioned above (corruption, operators' strategic behavior, etc.). ${ }^{24}$

The intuition can be readily explained taking the case of the price cap dummy $(P C)$. For each observation, i.e. a given project in country $n$, sector $s$, we compute the average prevalence, at the time the contract is signed, of price cap regulation for projects in the same sector in different countries (we denote this variable by $P C_{-} S_{-}$ins), and in different sectors in different countries (denoted by $P C_{-} N S_{-}$ins). For example, to instrument the choice of price regulation in a water project in Brazil in 1997, we will use the average prevalence of price cap regulation in water in all other countries at that time, as well as the average prevalence of price cap regulation in transport in all other countries at that time.

The relevance of these two variables comes from the fact that, with the correlation between the choice of price cap regulation and unobserved variables likely being composed of country- and operator-specific effects, the choice of price cap regulation will only be correlated across different countries (and different sectors) through some additional aspects that are independent of these specific effects. Obvious examples would be the existence of a global sectorial technological trend implying common shifts in specific contractual choices, common efficiency reasons (e.g. capital intensity) favoring certain clauses across countries, or the existence of a worldwide trend or mode effect in favor of a certain type of policy (e.g. in the case of price regulation or minimum income guarantees), that may be common across countries for example because of recommendations from international institutions such as the Worldbank or other donors.

Furthermore, the rationale for introducing the $\_N S$ _ ins variables is that

\footnotetext{
${ }^{24}$ We are indebted to Fiona Scott-Morton for suggesting this to us. Examples are Berry, Levinsohn and Pakes (1995), where product characteristics and prices are instrumented using characteristics and prices of other substitute products, and Holtz-Eakin (1994), who instruments US state level public capital by using other states' levels of public capital.
} 
when looking at the same sector across countries, there still exists the risk that some operators be present in several countries, thus reintroducing some correlation through firm-specific effects. Note however that while this risk may be significant for water projects, given that a few firms tend to operate in many countries worldwide, it is much less so for transport projects where local consortia are often in charge of concessions.

Summarizing, the choice of contractual variables will be determined by country level characteristics (see below), a common error term across countries, capturing a general trend and other non-country-specific effects, and an error term including country- and operator-specific aspects. Using the instruments defined above, we are thus able to control for the self-selection effect in contract determination.

Given this set of instruments, we test the potential endogeneity of all the contractual variables applying the simple Rivers-Vuong (1988) test. ${ }^{25}$ The first stage estimations, shown in Table A3 in the Appendix, include, on top of the instruments developed above, a measure of the country per capita GDP, a sector dummy, corruption, bureaucracy quality, rule of law, and the existence of regulatory body, all of which are exogenous in the sense that they are not determined by the risk of potential renegotiations, although they may not be excludable. Their inclusion makes first stage estimations more accurate. For example, in the case of price cap, Laffont (2005) develops a model showing that the choice of the type of price regulation can be explained by this set of variables, which he then successfully tests with cross-country data. We expect other contractual dimensions to be similarly determined by a combination of a country's level of development and institutional characteristics.

The results of the test, which standard errors are bootstrapped to account of the potential correlation of errors over time, show that exogeneity is rejected for the price cap (at 1\%), investment requirements (at 1\%), private financing (at 1\%), minimum income guarantee (at 10\%) and bidding process (at $1 \%$ ) variables.

Having determined which contractual variables are to be instrumented, we make use of a two-stage procedure to address the potential endogeneity of contract clauses. ${ }^{26}$ Although such an estimation is in principle biased when the endogenous variable is binary (see Wooldridge, 2002), support for it can

\footnotetext{
${ }^{25}$ Note that this test is valid even when the endogenous variable is binary (Wooldridge, 2002).

${ }^{26}$ Second stage standard errors are adjusted using a bootstrapping procedure.
} 
be found in Angrist (1991), who states based on a Monte Carlo study that the bias is negligible and the performance of IV estimates is comparable to that of estimates computed using the correct likelihood function.

Angrist (2002) further justifies the use of a simple two-stage IV estimation as long as the focus is on causal effects rather than structural parameters. One related caveat will thus be that marginal effects should be taken with some caution when IV estimates are performed.

Therefore, to reinforce confidence in our estimates, we compare them with the results from a linear probability model (LPM) estimated by twostage least squares. Linear probability model have been used in similar applications with endogenous binary variables. ${ }^{27}$ Here, we specifically apply a procedure described in Wooldridge ${ }^{28}$, which consists in estimating a linear second stage by IV using the fitted value from the first stage probit as instruments. Wooldridge (2002) shows that the 2SLS standard errors and test statistics are asymptotically valid and that the IV estimator from such an estimation is asymptotically efficient. Moreover, the procedure is robust to alternative specifications of the first stage probit. The results (marginal effects and significance) from 2SLS are very much in line with the other results, giving confidence in our estimation strategy.

Going now to the results, note that there are good intuitive reasons for the results of the exogeneity test. Indeed, we would expect contractual aspects that are routinely predetermined to be exogenous as they are unlikely to be altered by subsequent strategic interactions between the government and potential concessionaires. This is obviously the case of the award criteria and of the inclusion of an arbitration process, which generally depends on the existing legal framework.

On the other hand, it is sometimes the case that concessions are granted on the basis of materials that focus on technical criteria and requirements but are drafted in the absence of sector laws and regulatory expertise and only weakly delineate what future regulation and tariff adjustment rules would be (Guasch, 2004). The use of a bidding procedure rather than a direct negotiation with potential operators also unsurprisingly depends on the characteristics of both projects and candidate concessionaires, as shown for example by Bajari, McMillan and Tadelis (2003) in the context of private sector building contracts. Similarly, as argued in GLS, the exact structure of investments

\footnotetext{
${ }^{27}$ See for Example Carrasco (2001).

${ }^{28}$ Chapter 18, pages $621-25$.
} 
and financing, as well as the inclusion of guarantee clauses, are likely to result from strategic considerations concerning the attractiveness of a concession to private operators and the degree of risk involved.

Before going to the results, we discuss briefly the first stage estimations for the variables deemed endogenous. Note that for each of these, at least one of our_S_ins and _ $N S$ _ins instrumental variables is significant, which is an indication of the relevance of our instrumental strategy.

The choice of regulation appears to hinge mostly on the quality of institutions. Price cap regulation is less likely when the bureaucracy is more efficient, capturing perhaps the enhanced ability of bureaucrats to manage informationally demanding schemes like rate of return regulation (this is further supported by the negative sign of the existence of a regulator variable). On the other hand, more generic measures like corruption and rule of law appear to have the opposite effect. One possibility is that price caps are less attractive for government in environments characterized by higher risk of bribery and weak enforcement. However, overall the bureaucratic efficiency effect seems to dominate.

Investment requirements appear more frequent when corruption is lower, and in the transport sector, where greenfield projects are more likely. As for exclusive private financing, it dominates in the transport sector (where the size of the required investments is also likely to be higher, exceeding public finance capacity). The existence of a regulator ex ante also increases the probability of some government participation in financing, maybe because it represents the implicit guarantee of better administrative control over the project. A better bureaucracy makes private financing more likely, probably capturing the fact that better bureaucrats find it easier to convince private investors of the convenience to invest. As for corruption, it has the opposite effect, which can be related to the effect commonly observed in FDI studies, showing that private investors prefer direct involvement in situations of weak governance for risk sharing purposes (Straub, 2005).

Bidding is more frequently used for water concessions, a finding in accordance with results from Bajari, McMillan and Tadelis (2003) for example, to the extent that transport projects are more complex and involve more ex ante uncertainty, in particular in terms of demand forecasts. The effect of institutional variables indicates that bidding is more attractive if the environment is less corrupt, while a better trained bureaucracy makes the direct negotiation option more relevant.

Finally, minimum income guarantee clauses are especially prevalent in 
transport projects, again probably due to the high uncertainty surrounding future demand and as a way to make them attractive to private investors (see Engel et al. 2003 and INCO, 2004). Such clauses also appear to be more likely when a regulator is present.

\subsection{Results}

Tables 3 shows the basic specifications. Table 4 presents instrumental variable estimations (in panels (A) and (B)), where we make use of the two-stage procedure to address the potential endogeneity of contract clauses. Panel (C) includes 2SLS as robustness checks. ${ }^{29}$ Table 5 introduces additional robustness checks, including variables and interactions related to institutional and political aspects.

(Table 3 here)

Note finally that in all specifications, we avoid introducing the price cap and the private financing variables together for concerns of multicollinearity. Indeed, as argued in Laffont (1996), there is a potential link between the ownership structure, which determines to what the current political majority is able to capture the rents resulting from the existing incentive scheme, and the type of price regulation that would prevail. ${ }^{30}$ Therefore, when private financing is added to our specifications, in column 2 of Table 3 and in column 4 of Table 4 , we exclude the price cap variable. ${ }^{31}$

We present the main results for the determinants of government-led renegotiation below, making special mention of how they relate to similar estimations in GLS. We discuss first the core variables.

- The existence of a regulatory body is again negative and significant most of the time. Its economic impact, however, appears to be smaller (about half) of what it is for firm-led renegotiations. Also, we again observe that it somewhat loses statistical significance when instrumental estimations are performed, which we interpret as being linked to the fact that this variable is used in the first stage estimation and that it is effective through better contract clauses.

\footnotetext{
${ }^{29}$ As can be seen from the table and the discussion of marginal effects below, 2SLS very much support the results from the probit analysis.

${ }^{30}$ We thank a referee for signaling this to us.

${ }^{31}$ Indeed, when both variables are included together, we observe that the price cap variable loses significance.
} 
- The price cap variable, which is one of the most important result in the context of firm-led renegotiations, does again take a positive sign in Table 4 . When instrumented in Table 5, it is positive and strongly significant. Thus, the risk effect of price cap regulation (renegotiation to relax an excessively stringent cap) appears to dominate a potential rent-shifting motive (government renegotiation to limit excessive rents due to a loose cap), with marginal effects of 12 to $15 \%$ in both the probit and the LPM.

- Duration since award is positive and very significant.

- The existence of investment requirements does not yield consistent results in Table 3, being generally not significant. However, when instrumented, the investment variable changes sign and becomes negative and significant. Its marginal effect is between 3 and $6 \%$.

- The quality of bureaucracy is still negative and significant throughout. However, the corruption variable, whether introduced alone or together with the quality of bureaucracy index, is positive and significant in Table 3, meaning that a less corrupt environment is conducive to more renegotiation. This is consistent with our theoretical framework that implies a reverse effect for that variable. Intuitively, the quality of the bureaucracy dimension may be related to a contract-improving effect similar to the one linked to the existence of a regulator, while corruption would capture the standard effect through the $\pi(x)$ function.

- The lagged election variable is still positive, implying more renegotiations after national elections. Its significance varies between 2 and $5 \%$ depending on what other variables are included in the specification. Note that substituting this variable with a dummy indicating effective political changes following elections yields very similar results. ${ }^{32}$

- The economic cycle has again an impact on the probability of renegotiations, with lagged growth shocks implying more renegotiations. They appear however to matter slightly less (this makes sense if a significant fraction of renegotiations are rather linked to the political cycle) and in a different way than for firm-led renegotiations: The marginal effect is lower (around +0.5 and $+0.2 \%$ after one and two years respectively for each one-point decrease in

\footnotetext{
${ }^{32}$ This variable is defined by imputing as changes cases in which there was a shift in the dominant party majority in Congress, or a new president coming from a different party than his or her predecessor. Given that the scope of many concessions (especially in water) is limited to local or regional political districts, we would need to construct similar reliable variables (elections and effective changes of majority) at the level of the relevant local elections to be able to test the effect of political turnover more precisely.
} 
the growth rate), and the effect is stronger with a one year lag and decreases after that. A similar pattern is observed for exchange rate shocks. ${ }^{33}$

Additional variables introduced in Table 3 include:

- Exclusive private financing has a reducing effect on the probability of renegotiations, and appears to be strongly significant both in Table 3 and when instrumented in Table 4. Its marginal effect is between $12 \%$ (probit) and $14 \%$ (LPM).

- The existence of an arbitration process, which we had previously related to the cost of renegotiation, is here negative and significant (Table 3, column 3). Exogeneity is accepted for this variable.

- Minimum income guarantee is consistently positive and strongly significant, and this carries over when it is instrumented (Table 4). Its marginal effect is between 4\% (LPM) and 5\% (probit), which indicates the inappropriateness of such clauses. In the case of Colombia's road program, the cumulated amount of guarantees due by the State to concessionaires as of 2004 amounts approximately to the equivalent of US\$100 million, threatening to weight heavily on future fiscal results. For this reason, least present value of revenue auctions have been introduced for new concessions awards, as a way to substitute for this type of guarantees (INCO, 2004).

- The existence of a bidding process previous to the award of the concession is positive and significant (Table 3, column 4). This effect remains when performing IV estimates. As discussed in GLS, the existence of a bidding procedure may generate several conflicting effects (strategic underbidding, selection of more efficient firms, reduction of their potential profits), and the way these interact to produce the net positive effect we observe is difficult to analyze. The marginal effect is between 10\% (LPM) and $12 \%$ (probit).

- A dummy variable classifying award criteria (1 for highest price, highest canon or lowest subsidy, hence monetary transfer considerations not prone to subsequent interpretational subjectivity, 0 for others), shows up negative and significant (table 4, column 7). Note that exogeneity is accepted for that variable. Therefore, less manipulable criteria seem to have some reducing impact on the possibility of subsequent renegotiations. ${ }^{34}$

(Table 4 here)

\footnotetext{
${ }^{33}$ Results are not shown here to save space.

${ }^{34}$ These results call for further inquiry, but are left for future research. See Engel, Fischer and Galetovic (2001 and 2003) for a discussion of award criteria, including their proposal of a least present value of revenue auction.
} 
The next section digs further into the institutional and regulatory environment of successful concessions.

\subsection{Institutional and Political Aspects}

Table 5 introduces additional robustness checks, including some interactions meant to explore further the impact of institutional and political aspects.

In column 1, we interact the dummy variable for the existence of a regulator with the corruption index. The interaction is positive and significant at the $1 \%$ level, while the dummy for the existence of a regulator remains negative and significant. Considering that a higher value of the corruption index corresponds to a less corrupt environment, this can be interpreted by saying that the stronger corruption, the more important the effect of having a regulator in place to limit the incidence of renegotiations. This results indicates that the impact of a regulatory body is especially important in weak governance environments.

(Table 5 here)

To explore whether the effect of political cycles is affected by the general perceived quality of institutions, in column 2 we interact the election variable with the corruption index, which yields a negative and significant sign, and in column 3 we obtain a similar negative and significant result by interacting the quality of the bureaucracy index with the election variable. This shows that the better the bureaucracy, the milder the post-election effect.

Overall these results give additional evidence of the fact that strong regulatory mechanisms are specially important when the institutional quality is low. In this context, experienced and independent regulators are likely to act as barriers against political opportunism. ${ }^{35}$ Note also that Guasch (2004) presents results that confirm our findings, based on an extended sample covering almost 900 concessions in 15 countries. ${ }^{36}$

In our model, government-led renegotiations are both Pareto improving and rent shifting ones. Empirically, our sample contains a small number of renegotiations that are considered to be the result of a joint call. As

\footnotetext{
${ }^{35}$ See Cubbin and Stern (2005) and Wallsten (2001), for cross-country evidence that improved regulatory independence and quality have a positive impact on performance and efficiency in the electricity and telecommunication sectors respectively.

${ }^{36}$ This sample include energy and telecommunications projects.
} 
discussed in GLS, this may both reflect the fact that the renegotiation was desired by both parties or that there was not a clear case to attribute the call, as with some Mexican road projects. In any case, it can be argued that joint calls are close in nature to Pareto improving government calls, so Table 5 presents robustness checks using as a dependent variable the dummy variable indicating whether there is a renegotiation initiated by the government or by both parties. Overall, the main results are unchanged.

\section{Conclusion and Policy Implications}

Using a sample of 307 Latin American transport and water concessions in the 1990s, we have tested the determinants of government-led renegotiations and implemented an original instrumental variable approach to deal with potential contractual endogeneity.

Overall, the analysis of government-led renegotiations confirms some of the main insight that Guasch, Laffont and Straub (2003) presented with respect to firm-led renegotiation. Concessions' fragility is due to a mix of flaws in contract design, inadequate regulatory frameworks and deficient institutional environments, and the impact of macroeconomic shocks. Key results are again the importance of having a regulator in place when awarding concessions and the sensitivity of price cap regulated concessions to shocks.

There are, however, important differences with firm-led renegotiations. Most importantly, the financing variables (those affecting the status quo payoffs of the renegotiating parties, as private financing and investment requirements) and the corruption variable tend to come out with reversed signs, which is what we should expect from the way they affect the firm and the government in the bargaining process.

Table 6 summarizes the results by showing the sign of the main determinants found to have an effect on both types of renegotiations. In particular, it highlights (shaded rows) that the sign of the investment, private financing and corruption variables are indeed reversed, which provides supports for the theoretical model presented in the first part of this paper. ${ }^{37}$ On the other hand, other unchanged results include the effect of elections, economic

\footnotetext{
${ }^{37}$ Since the estimations in GLS were based on a different set of instruments, Table 7 relies on results obtained when running estimations of firm-led renegotiations determinants with the same set of instruments used in the present paper.
} 
shocks, duration since award, as well as the inadequacy of minimum income guarantee clauses.

Table 6: Comparative summary of the results

\begin{tabular}{|l|c|c|}
\hline & $\begin{array}{c}\text { Government-led } \\
\text { renegotiation }\end{array}$ & Firm-led renegotiation \\
\hline Existence of a regulator & Negative & Negative \\
\hline Price cap regulation & Positive & Positive \\
\hline Duration & Positive & Positive \\
\hline Investment requirements & Negative & Positive \\
\hline Private financing & Negative & Positive \\
\hline Quality of bureaucracy & Negative & Negative \\
\hline Corruption & Positive & Negative \\
\hline Elections & Positive & Positive \\
\hline Growth & Negative & Negative \\
\hline Minimum income guarantee & Positive & Positive \\
\hline
\end{tabular}

Additional policy insights come from better and more precise evidence of the link between the regulatory framework and the institutional and political environment. Indeed, it appears that having efficient and independent regulatory authorities in place when awarding concessions is especially important because it helps limit the damaging effects of corruption, weakness in the rule of law and the bureaucratic framework, as well as the potential strategic behavior of the government following changes in power. 


\section{References}

Aghion, P., M. Dewatripont and P. Rey (1994), "Renegotiation Design with Unverifiable Information", Econometrica, 62(2), 257-282.

Angrist, J. (1991), "Instrumental Variables Estimation of Average Treatment Effects in Econometrics and Epidemiology", National Bureau of Economic Research Technical Working Paper Number 115.

Angrist, J. (2001), "Estimation of Limited Dependent Variable Models with Dummy Endogenous Regressors: Simple Strategies for Empirical Practice", Journal of Business and Economic Statistics, 19(1), 2-29.

Aubert, C. and J.J. Laffont (2002), "Political Renegotiation of Regulatory Contracts", mimeo, Toulouse.

Bajari P., R. McMillan and S. Tadelis (2003), "Auctions versus Negotiations in Procurement: An Empirical Analysis", NBER working paper 9757.

Bajari P., S. Houghton and S. Tadelis (2006), "Bidding for Incomplete Contracts: An Empirical Analysis", mimeo.

Berry, S., J. Levinsohn and A. Pakes (1995), "Automobile Prices in Market Equilibrium", Econometrica, 63(4), 841-890.

Besley, T. and S. Coate (2003), "Elected versus Appointed Regulators: Theory and Evidence", Journal of the European Economic Association, 1(5), 1176-1206.

Carrasco R. (2001), "Binary Choice with Binary Endogenous Regressors in Panel Data: Estimating the effect of Fertility on Female Labor Participation", Journal of Business and Economic Statistics, 19(4), 385-394.

Chakravarty S. and B. MacLeod (2003), "On the Efficiency of Standard Form Contracts: The Case of Construction", USC CLEO research paper C04-17.

Chiappori, P.A. and B. Salanié (2003) "Testing Contract Theory: a Survey of Some Recent Work", in Advances in Economics and Econometrics - Theory and Applications, Eighth World Congress, M. Dewatripont, L. Hansen and P. Turnovsky, eds., Econometric Society Monographs, Cambridge University Press, Cambridge, 115-149.

Crocker, K. and K. Reynolds (1993), "The Efficiency of Incomplete Contracts: An Empirical Analysis of Air Force Engine Procurement", Rand Journal of Economics, 24, 126-146.

Cubbin, J. and J. Stern (2005), "Regulatory Effectiveness : The Impact of Regulation and Regulatory Governance Arrangements on Electricity Industry Outcomes", World Bank Policy Research Working Paper 3536, Wash- 
ington D.C.

Dewatripont, M. (1986), "Renegotiation and Information Revelation over Time in Optimal Labor Contracts", Quarterly Journal of Economics, 104, 589-620.

Engel, E., R. Fischer and A. Galetovic (2003), "Privatizing Highways in Latin America: Fixing What Went Wrong", Economia, 4(1), 129-164.

Engel, E., R. Fischer and A. Galetovic (2001), "Least Present Value of Revenue Auctions and Highway Franchising", Journal of Political Economy, 109(5), 993-1020.

Estache A., L. Guasch and L. Trujillo, (2003), "Price Caps, Efficiency Payoffs, and Infrastructure Contract Renegotiation in Latin America", World Bank Policy Research Working Paper 3129, Washington D.C.

Gil, R. (2005), ""Make-or-Buy" in Movies: Integration and Ex-post Renegotiation", mimeo, UCSB.

Green, J. and J.J. Laffont (1992), "Renegotiation and the Form of Efficient Contracts", Annales d'Economie et de Statistique, 25/26, 123-150.

Guasch, L. (2004), Granting and Renegotiating Concessions. Doing it Right, World Bank Institute Development Studies, Washington D.C.

Guasch, L. and P. Spiller, (1999), Managing the Regulatory Process: Design, Concepts, Issues and the Latin American and Caribbean Story, The World Bank, Washington D.C.

Guasch, Laffont and Straub (2003), "Renegotiation of Concession Contracts in Latin America", World Bank Policy Research Working Paper 3011.

Guasch, Laffont and Straub (2005), "Infrastructure Concessions in Latin America : Government-led Renegotiations", World Bank Policy Research Working Paper 3749.

Guasch, Laffont and Straub (2006), "Renegotiation of Concession Contracts: A Theoretical Approach", Review of Industrial Organization, forthcoming.

Harris, C. (2003) "Private Participation in Infrastructure in Developing Countries. Trends, Impacts, and Policy Lessons", World Bank Working Paper No.5, Washington D.C.

Hart, O., and J. Moore (1988), "Incomplete Contracts and Renegotiation", Econometrica, 56, 755-785.

Hart, O., and J. Tirole (1988), "Contract Renegotiation and Coasian Dynamics", Review of Economics Studies, 55, 509-540.

Holtz-Eakin, D. (1994) "Public-Sector Capital and the Productivity Puzzle", The Review of Economics and Statistics, 76, 12-21. 
INCO (2004), "Alternativas de Reestructuración para las Concesiones de Carreteras y Ferrocarriles", mimeo, Instituto Nacional de Concesiones, Bogotá.

Laffont, J.J. (2005), Regulation and Development, Cambridge University Press.

Laffont, J.J. (1996), "Industrial Policy and Politics", International Journal of Industrial Organization, Vol. 14, 1-27.

Laffont, J.J. and D. Martimort (2002), The Theory of Incentives I, The Principal-Agent Model, Princeton University Press, Princeton.

Laffont, J.J. and J. Tirole (1993), A Theory of Incentives in Procurement and Regulation, Third Printing. Cambridge, United States: MIT Press.

Laffont, J.J. and J. Tirole (1990), "Adverse Selection and Renegotiation in Procurement", Review of Economic Studies, 75, 597-626.

Rivers D. and Q. Vuong (1988), "Limited Information Estimators and Exogeneity Tests for Simultaneous Probit Models", Journal of Econometrics, 39, 347-366.

Rose-Ackerman, S. (1999), Corruption and Government: Causes, Consequences, and Reform, Cambridge: Cambridge University Press.

Segal, I. and M. Whinston (2002), "The Mirrlees Approach to Mechanism Design with Renegotiation (with Applications to Hold-Up and Risk Sharing)", Econometrica, 70(1), 1-46.

Straub, S. (2005), "Opportunism, Corruption, and the Multinational Firm's Mode of Entry", mimeo, University of Edinburgh.

Wallsten, S. (2001), "An Econometric Analysis of Telecom Competition, Privatization, and Regulation in Africa and Latin America", The Journal of Industrial Economics, 49(1), 1-19.

Wooldridge, J.M. (2002), Econometric Analysis of Cross Section and Panel Data, Cambridge, MA: MIT Press. 


\section{Appendix}

Table A1: List of variables, source and summary statistics

\begin{tabular}{|c|c|c|}
\hline CHARACTERISTICS OF CONCESSIONS & & \\
\hline $\begin{array}{c}\text { Dummy variables, } 1=\text { Yes, } 0=\text { No } \\
\end{array}$ & Yes & No \\
\hline $\begin{array}{l}\text { Renegotiation: Dummy variable indicating whether there was or not a } \\
\text { renegotiation of the concession contract. }\end{array}$ & $162(52.8 \%)$ & $145(47.2 \%)$ \\
\hline Renegotiation initiated by the firm & 53 & 254 \\
\hline Renegotiation initiated by the government & 94 & 213 \\
\hline Renegotiation initiated by both & 15 & 292 \\
\hline $\begin{array}{l}\text { Existence of regulatory body: Dummy variable indicating whether there was or not } \\
\text { a regulatory body at the time of the concession first coming into operation. }\end{array}$ & $180(58.6 \%)$ & $127(41.4 \%)$ \\
\hline $\begin{array}{l}\text { Regulatory body is part of the government ministry: Dummy variable indicating } \\
\text { whether the regulatory body is constituted as a part of the government ministry or } \\
\text { not. }\end{array}$ & $293(95.7 \%)$ & $13(4.3 \%)$ \\
\hline $\begin{array}{l}\text { Price cap: Dummy variable indicating whether the tariff regulation imposed by the } \\
\text { regulator is a price cap. }\end{array}$ & $283(92.2 \%)$ & $24(7.8 \%)$ \\
\hline $\begin{array}{l}\text { Investment requirements: Dummy variable indicating whether there are or not } \\
\text { investment requirements as part of the concession contract. }\end{array}$ & $235(76.5 \%)$ & $72(23.5 \%)$ \\
\hline $\begin{array}{l}\text { Private financing: Dummy variable indicating whether the project is funded } \\
\text { entirely through private funds (without any financial investment of the state, } \\
\text { whether local or national) or not. }\end{array}$ & $160(61.1 \%)$ & $102(38.9 \%)$ \\
\hline $\begin{array}{l}\text { Bidding process: Dummy variable indicating whether there was or not a bidding } \\
\text { process to award the concession. }\end{array}$ & $272(88.6 \%)$ & $35(11.4 \%)$ \\
\hline $\begin{array}{l}\text { Award criteria: Dummy variable classifying award criteria (1 for highest price, } \\
\text { highest canon or lowest subsidy, } 0 \text { for all others) }\end{array}$ & $106(34.5 \%)$ & $201(65.5 \%)$ \\
\hline $\begin{array}{l}\text { Minimum income guarantee: Dummy variable indicating whether there is or not a } \\
\text { government guarantee in terms of minimum income promissory. }\end{array}$ & $63(20.5 \%)$ & $244(79.5 \%)$ \\
\hline $\begin{array}{l}\text { Arbitration process: Dummy variable indicating whether there is or not a formal } \\
\text { set of arbitration processes stated in the contract providing for the settlement of a } \\
\text { dispute between the concession holder and the government, should such a situation } \\
\text { arise. }\end{array}$ & $179(58.3 \%)$ & $128(41.7 \%)$ \\
\hline \multicolumn{3}{|l|}{$\begin{array}{c}\text { CHARACTERISTICS OF THE ENVIRONMENT } \\
\end{array}$} \\
\hline \multicolumn{3}{|l|}{ Dummy variables, $1=$ Yes, $0=$ No } \\
\hline $\begin{array}{l}\text { Election: Dummy variable indicating whether there were or not national elections } \\
\text { (legislative or presidential) in any given year. Source: Political Database of the } \\
\text { Americas. Georgetown University/Organization of American States. Center for } \\
\text { Latin American Studies. }\end{array}$ & n.r. & n.r. \\
\hline $\begin{array}{l}\text { Political Change: Dummy variable indicating whether there were or not a change } \\
\text { in power following national elections (legislative or presidential) in any given } \\
\text { year. Source: Political Database of the Americas. Georgetown } \\
\text { University/Organization of American States. Center for Latin American Studies. }\end{array}$ & n.r. & n.r. \\
\hline $\begin{array}{l}\text { Continuous variables } \\
\end{array}$ & Mean & S.D. \\
\hline $\begin{array}{l}\text { Duration since award: Indicates the number of years a concession has been in } \\
\text { operation since its award. }\end{array}$ & n.r. & n.r. \\
\hline $\begin{array}{l}\text { Corruption: Index from Political Risk Service, International Country Risk Guide; } \\
\text { annual values from } 1989 \text { to } 1995 \text {, and } 1998 \text { value after that. Range from } 1 \text { to } 6 . \\
\text { Higher value means less corruption. }\end{array}$ & 2.94 & 0.69 \\
\hline $\begin{array}{l}\text { Rule of law: Index from Political Risk Service, International Country Risk Guide; } \\
\text { annual values from } 1989 \text { to } 1995 \text {, and } 1998 \text { value after that. Range from } 1 \text { to } 6 . \\
\text { Higher value means better rule of law. }\end{array}$ & 2.92 & 0.99 \\
\hline $\begin{array}{l}\text { Bureaucratic quality: Index from Political Risk Service, International Country } \\
\text { Risk Guide; annual values from } 1989 \text { to } 1995 \text {, and } 1998 \text { value after that. Range } \\
\text { from } 1 \text { to 6. Higher value means better bureaucratic quality. }\end{array}$ & 3.36 & 0.61 \\
\hline \multicolumn{3}{|l|}{ GDP per capita } \\
\hline $\begin{array}{l}\text { Growth: Yearly growth rate of GDP in real terms. Source: World Bank and Inter- } \\
\text { American Development Bank. }\end{array}$ & n.r. & n.r. \\
\hline $\begin{array}{l}\text { Exchange rate: Annual evolution of the real exchange ratet (calculated as (index } \\
\text { rate of year } \mathrm{t} \text { - index rate of year } \mathrm{t}-1 \text { )/index rate of year } \mathrm{t} \text { ). A positive value } \\
\text { indicates depreciation. Source: Inter-American Development Bank. }\end{array}$ & n.r. & n.r. \\
\hline
\end{tabular}
indicates depreciation. Source: Inter-American Development Bank.

Note: For variables varying over time, like the election dummy, duration since award, and macroeconomic variables, the summary statistics are omitted (denoted by n.r.: non relevant). 
Table A2: Incidence of renegotiations according to characteristics

\begin{tabular}{|c|c|c|c|c|}
\hline RENEGOTIATION & \multicolumn{2}{|c|}{ Yes (162) } & \multicolumn{2}{|c|}{ No (145) } \\
\hline Characteristics of Concessions & Yes & No & Yes & No \\
\hline Existence of regulatory body & $44.4 \%$ & $55.6 \%$ & $74.5 \%$ & $25.5 \%$ \\
\hline Regulatory body is part of the government ministry & $100 \%$ & $0 \%$ & $91.0 \%$ & $9.0 \%$ \\
\hline Price cap & $95.1 \%$ & $4.9 \%$ & $89.0 \%$ & $11.0 \%$ \\
\hline Investment requirements & $75.9 \%$ & $24.1 \%$ & $77.2 \%$ & $22.8 \%$ \\
\hline Private financing & $48.5 \%$ & $51.5 \%$ & $74.6 \%$ & $25.4 \%$ \\
\hline Bidding process & $89.5 \%$ & $10.5 \%$ & $87.6 \%$ & $12.4 \%$ \\
\hline Award criteria & $17.9 \%$ & $82.1 \%$ & $53.1 \%$ & $46.9 \%$ \\
\hline Minimum income guarantee & $29.0 \%$ & $71.0 \%$ & $11.0 \%$ & $89.0 \%$ \\
\hline Arbitration process & $42.6 \%$ & $57.4 \%$ & $75.9 \%$ & $24.1 \%$ \\
\hline RENEGOTIATION INITIATED BY THE GOVERNMENT & \multicolumn{2}{|c|}{ Yes (94) } & \multicolumn{2}{|c|}{ No (213) } \\
\hline Characteristics of Concessions & Yes & No & Yes & No \\
\hline Existence of regulatory body & $37.2 \%$ & $62.8 \%$ & $68.1 \%$ & $31.9 \%$ \\
\hline Regulatory body is part of the government ministry & $100 \%$ & $0 \%$ & $93.9 \%$ & $6.1 \%$ \\
\hline Price cap & $97.9 \%$ & $2.1 \%$ & $89.7 \%$ & $10.3 \%$ \\
\hline Investment requirements & $61.7 \%$ & $38.3 \%$ & $83.1 \%$ & $16.9 \%$ \\
\hline Private financing & $20.3 \%$ & $79.7 \%$ & $75.6 \%$ & $24.4 \%$ \\
\hline Bidding process & $97.9 \%$ & $2.1 \%$ & $84.5 \%$ & $15.5 \%$ \\
\hline Award criteria & $1.1 \%$ & $98.9 \%$ & $49.3 \%$ & $50.7 \%$ \\
\hline Minimum income guarantee & $22.3 \%$ & $77.7 \%$ & $19.7 \%$ & $80.3 \%$ \\
\hline Arbitration process & $18.1 \%$ & $81.9 \%$ & $76.1 \%$ & $23.9 \%$ \\
\hline
\end{tabular}

Note: 306 Observations for Regulatory body is part of the government ministry, 262 Observations for private financing. 
Table A3: First stage estimations.

\begin{tabular}{|c|c|c|c|c|c|c|c|}
\hline & (1) & (2) & (3) & (4) & (5) & (6) & (7) \\
\hline & $\begin{array}{l}\text { Price cap } \\
\text { (PC) }\end{array}$ & $\begin{array}{l}\text { Investment } \\
\text { requirements } \\
\text { (IR) }\end{array}$ & $\begin{array}{l}\text { Private } \\
\text { financing } \\
(\mathrm{PF})\end{array}$ & $\begin{array}{l}\text { Award } \\
\text { criteria (AC) }\end{array}$ & $\begin{array}{l}\text { Arbitration } \\
\text { process (AP) }\end{array}$ & $\begin{array}{l}\text { Min. income } \\
\text { guarantee } \\
\text { (MI) }\end{array}$ & $\begin{array}{l}\text { Bidding } \\
\text { process (BP) }\end{array}$ \\
\hline Constant & $\begin{array}{l}50.574 \\
(32.985)\end{array}$ & $\begin{array}{l}6.218 \\
(1.209)^{* * *}\end{array}$ & $\begin{array}{l}2.366 \\
(1.415)^{*}\end{array}$ & $\begin{array}{l}-3.399 \\
(1.211)^{* * *}\end{array}$ & $\begin{array}{l}14.376 \\
(6.762)^{* *}\end{array}$ & $\begin{array}{l}14.723 \\
(3.502)^{* * *}\end{array}$ & $\begin{array}{l}4.765 \\
(3.719)\end{array}$ \\
\hline Per capita GDP & $\begin{array}{l}0.000 \\
(0.000)\end{array}$ & $\begin{array}{l}-0.000 \\
(0.000)\end{array}$ & $\begin{array}{l}-0.000 \\
(0.000)\end{array}$ & $\begin{array}{l}0.001 \\
(0.000)^{* * *}\end{array}$ & $\begin{array}{l}0.002 \\
(0.000) * * *\end{array}$ & $\begin{array}{l}-0.002 \\
(0.000)^{* * *}\end{array}$ & $\begin{array}{l}0.000 \\
(0.000)\end{array}$ \\
\hline $\begin{array}{l}\text { Existence of } \\
\text { regulatory body }\end{array}$ & $\begin{array}{l}-3.823 \\
(1.585)^{* *}\end{array}$ & $\begin{array}{l}0.018 \\
(0.354)\end{array}$ & $\begin{array}{l}-1.584 \\
(0.477)^{* * *}\end{array}$ & $\begin{array}{l}-0.480 \\
(0.313)\end{array}$ & $\begin{array}{l}-1.219 \\
(0.668)^{*}\end{array}$ & $\begin{array}{l}-2.215 \\
(1.639)\end{array}$ & $\begin{array}{l}0.940 \\
(0.351)^{* * *}\end{array}$ \\
\hline Corruption & $\begin{array}{l}1.192 \\
(0.450)^{* * *}\end{array}$ & $\begin{array}{l}0.332 \\
(0.186)^{*}\end{array}$ & $\begin{array}{l}-0.240 \\
(0.200)\end{array}$ & $\begin{array}{l}0.142 \\
(0.185)\end{array}$ & $\begin{array}{l}3.978 \\
(1.223)^{* * *}\end{array}$ & $\begin{array}{l}-0.095 \\
(0.185)\end{array}$ & $\begin{array}{l}0.844 \\
(0.186)^{* * *}\end{array}$ \\
\hline $\begin{array}{l}\text { Bureaucratic } \\
\text { quality }\end{array}$ & $\begin{array}{l}-3.084 \\
(0.767)^{* * *}\end{array}$ & $\begin{array}{l}-0.297 \\
(0.192)\end{array}$ & $\begin{array}{l}0.476 \\
(0.251)^{*}\end{array}$ & $\begin{array}{l}-0.095 \\
(0.180)\end{array}$ & $\begin{array}{l}1.904 \\
(0.467)^{* * *}\end{array}$ & $\begin{array}{l}0.008 \\
(0.256)\end{array}$ & $\begin{array}{l}-1.541 \\
(0.270)^{* * *}\end{array}$ \\
\hline Rule of law & $\begin{array}{l}0.237 \\
(0.496)\end{array}$ & $\begin{array}{l}-0.099 \\
(0.175)\end{array}$ & $\begin{array}{l}0.140 \\
(0.244)\end{array}$ & $\begin{array}{l}-0.635 \\
(0.185) * * *\end{array}$ & $\begin{array}{l}-1.700 \\
(0.665)^{* *}\end{array}$ & $\begin{array}{l}0.677 \\
(0.616)\end{array}$ & $\begin{array}{l}0.952 \\
(0.241)^{* * *}\end{array}$ \\
\hline $\begin{array}{l}\text { Water sector } \\
\text { dummy }\end{array}$ & $\begin{array}{l}-1.669 \\
(1.293)\end{array}$ & $\begin{array}{l}2.505 \\
(0.402)^{* * *}\end{array}$ & $\begin{array}{l}2.083 \\
(0.402)^{* * *}\end{array}$ & $\begin{array}{l}-3.258 \\
(0.549)^{* * *}\end{array}$ & $\begin{array}{l}-38.847 \\
(11.032)^{* * *}\end{array}$ & $\begin{array}{l}-4.481 \\
(1.548)^{* * *}\end{array}$ & $\begin{array}{l}2.006 \\
(0.554)^{* * *}\end{array}$ \\
\hline PC_S_ins & $\begin{array}{l}-63.268 \\
(26.357)^{* *}\end{array}$ & & & & & & \\
\hline PC_NS_ins & $\begin{array}{l}22.522 \\
(12.024)^{*}\end{array}$ & & & & & & \\
\hline IR_S_ins & & $\begin{array}{l}-3.506 \\
(0.589)^{* * *}\end{array}$ & & & & & \\
\hline IR_NS_ins & & $\begin{array}{l}-0.563 \\
(0.313)^{*}\end{array}$ & & & & & \\
\hline PF_S_ins & & & $\begin{array}{l}-0.265 \\
(0.459)\end{array}$ & & & & \\
\hline PF_NS_ins & & & $\begin{array}{l}-1.402 \\
(0.512)^{* * *}\end{array}$ & & & & \\
\hline AC_S_ins & & & & $\begin{array}{l}-0.049 \\
(0.395) \\
\end{array}$ & & & \\
\hline AC_NS_ins & & & & $\begin{array}{l}0.100 \\
(0.292) \\
\end{array}$ & & & \\
\hline AP_S_ins & & & & & $\begin{array}{l}-35.900 \\
(11.017)^{* * *}\end{array}$ & & \\
\hline AP_NS_ins & & & & & $\begin{array}{l}-1.649 \\
(0.779)^{* *}\end{array}$ & & \\
\hline MI_S_ins & & & & & & $\begin{array}{l}-3.865 \\
(1.817)^{* *}\end{array}$ & \\
\hline MI_NS_ins & & & & & & $\begin{array}{l}0.115 \\
(0.418)\end{array}$ & \\
\hline BP_S_ins & & & & & & & $\begin{array}{l}-7.045 \\
(1.226)^{* * *}\end{array}$ \\
\hline BP_NS_ins & & & & & & & $\begin{array}{l}2.069 \\
(2.368)\end{array}$ \\
\hline Observations & 307 & 307 & 262 & 307 & 296 & 305 & 307 \\
\hline
\end{tabular}

Probit estimations. Robust standard errors in parentheses. * significant at $10 \%$; ** significant at $5 \%$; $* * *$ significant at $1 \%$.

Specific instruments (_ins) are averages of same variable (denoted by the variable abbreviation, e.g. PC: price cap, IR: Investment requirements, etc.) in different countries, for the same sector (_S) and other sector (_NS) 
Table 3: Random effect probit panel

Basic estimations

\begin{tabular}{|c|c|c|c|c|c|c|c|}
\hline & $(1)$ & $(2)$ & (3) & (4) & (5) & $(6)$ & $(7)$ \\
\hline Dependent variable & $\begin{array}{l}\text { Reneg. } \\
\text { Initiated by } \\
\text { Govt }\end{array}$ & $\begin{array}{l}\text { Reneg. } \\
\text { Initiated by } \\
\text { Govt }\end{array}$ & $\begin{array}{c}\text { Reneg. } \\
\text { Initiated by } \\
\text { Govt }\end{array}$ & $\begin{array}{l}\text { Reneg. } \\
\text { Initiated by } \\
\text { Govt }\end{array}$ & $\begin{array}{l}\text { Reneg. } \\
\text { Initiated by } \\
\text { Govt }\end{array}$ & $\begin{array}{l}\text { Reneg. } \\
\text { Initiated by } \\
\text { Govt }\end{array}$ & $\begin{array}{c}\text { Reneg. } \\
\text { Initiated by } \\
\text { Govt }\end{array}$ \\
\hline $\begin{array}{l}\text { Existence of } \\
\text { regulatory body }\end{array}$ & $\begin{array}{l}-0.099 \\
(0.193) \\
\end{array}$ & $\begin{array}{c}-1.038^{* * *} \\
(0.291)\end{array}$ & $\begin{array}{l}-0.220 \\
(0.213) \\
\end{array}$ & $\begin{array}{c}-0.081 \\
(0.190) \\
\end{array}$ & $\begin{array}{c}1.054^{* * *} \\
(0.295)\end{array}$ & $\begin{array}{c}-0.140 \\
(0.196) \\
\end{array}$ & $\begin{array}{l}-0.316 \\
(0.220)\end{array}$ \\
\hline Price cap & $\begin{array}{c}0.786^{* *} \\
(0.320) \\
\end{array}$ & & $\begin{array}{c}0.381 \\
(0.340) \\
\end{array}$ & $\begin{array}{c}0.193 \\
(0.367) \\
\end{array}$ & $\begin{array}{c}0.310 \\
(0.393) \\
\end{array}$ & $\begin{array}{l}0.596^{*} \\
(0.337) \\
\end{array}$ & $\begin{array}{c}1.011^{* * *} \\
(0.315)\end{array}$ \\
\hline Duration since award & $\begin{array}{c}0.157^{* * *} \\
(0.038)\end{array}$ & $\begin{array}{c}0.312 * * * \\
(0.051)\end{array}$ & $\begin{array}{c}0.145^{* * *} \\
(0.040)\end{array}$ & $\begin{array}{c}0.197 * * * \\
(0.040)\end{array}$ & $\begin{array}{c}0.260^{* * *} \\
(0.045)\end{array}$ & $\begin{array}{c}0.135^{* * *} \\
(0.039)\end{array}$ & $\begin{array}{c}0.127 * * * \\
(0.041)\end{array}$ \\
\hline $\begin{array}{l}\text { Investment } \\
\text { requirements }\end{array}$ & $\begin{array}{c}0.028 \\
(0.164) \\
\end{array}$ & $\begin{array}{c}-0.397 * * \\
(0.199)\end{array}$ & $\begin{array}{c}0.066 \\
(0.170)\end{array}$ & $\begin{array}{c}0.053 \\
(0.165) \\
\end{array}$ & $\begin{array}{l}-0.181 \\
(0.176)\end{array}$ & $\begin{array}{c}0.010 \\
(0.165)\end{array}$ & $\begin{array}{l}-0.050 \\
(0.175)\end{array}$ \\
\hline Bureaucratic quality & $\begin{array}{c}-0.535^{* * *} \\
(0.114)\end{array}$ & $\begin{array}{c}-0.522^{* * *} \\
(0.143)\end{array}$ & $\begin{array}{c}-0.467 * * * \\
(0.126) \\
\end{array}$ & $\begin{array}{c}-0.627 * * * \\
(0.119) \\
\end{array}$ & $\begin{array}{c}-0.853^{* * * *} \\
(0.142)\end{array}$ & $\begin{array}{c}-0.485^{* * *} \\
(0.117)\end{array}$ & $\begin{array}{c}-0.459^{* * *} \\
(0.126) \\
\end{array}$ \\
\hline Election-1 & $\begin{array}{c}0.484^{* * *} \\
(0.125)\end{array}$ & $\begin{array}{c}0.215 \\
(0.163) \\
\end{array}$ & $\begin{array}{c}0.648^{* * *} \\
(0.137)\end{array}$ & $\begin{array}{c}0.476^{* * *} \\
(0.127)\end{array}$ & $\begin{array}{c}0.487 * * * \\
(0.133)\end{array}$ & $\begin{array}{c}0.531^{* * *} \\
(0.128)\end{array}$ & $\begin{array}{c}0.548^{* * *} \\
(0.132)\end{array}$ \\
\hline GDP growth -1 & $\begin{array}{c}-0.068^{* * *} \\
(0.018)\end{array}$ & $\begin{array}{c}-0.068^{* * *} \\
(0.021)\end{array}$ & $\begin{array}{c}-0.095^{* * *} \\
(0.020)\end{array}$ & $\begin{array}{c}-0.080^{* * * *} \\
(0.018) \\
\end{array}$ & $\begin{array}{c}-0.112^{* * *} \\
(0.021)\end{array}$ & $\begin{array}{c}-0.074^{* * *} \\
(0.018)\end{array}$ & $\begin{array}{c}-0.085^{* * *} \\
(0.020) \\
\end{array}$ \\
\hline GDP growth -2 & $\begin{array}{l}-0.026 \\
(0.026)\end{array}$ & $\begin{array}{l}-0.056^{*} \\
(0.029)\end{array}$ & $\begin{array}{l}-0.030 \\
(0.028)\end{array}$ & $\begin{array}{l}-0.025 \\
(0.026)\end{array}$ & $\begin{array}{l}-0.025 \\
(0.029)\end{array}$ & $\begin{array}{c}-0.031 \\
(0.026)\end{array}$ & $\begin{array}{l}-0.048^{*} \\
(0.029)\end{array}$ \\
\hline $\begin{array}{l}\text { Transport sector } \\
\text { Dummy }\end{array}$ & $\begin{array}{c}-0.961 * * * \\
(0.215)\end{array}$ & $\begin{array}{l}-0.217 \\
(0.303)\end{array}$ & $\begin{array}{l}-0.259 \\
(0.266)\end{array}$ & $\begin{array}{c}-0.932 * * * \\
(0.213)\end{array}$ & $\begin{array}{c}-1.860 * * * \\
(0.297)\end{array}$ & $\begin{array}{c}-1.111^{* * * *} \\
(0.229)\end{array}$ & $\begin{array}{l}-0.403 \\
(0.247)\end{array}$ \\
\hline Private financing & & $\begin{array}{c}-1.252 * * * \\
(0.206)\end{array}$ & & & & & \\
\hline Arbitration process & & & $\begin{array}{c}-1.035 * * * \\
(0.209) \\
\end{array}$ & & & & \\
\hline Bidding process & & & & $\begin{array}{c}1.148^{* * *} \\
(0.341)\end{array}$ & & & \\
\hline Corruption & & & & & $\begin{array}{c}0.954 * * * \\
(0.170)\end{array}$ & & \\
\hline $\begin{array}{l}\text { Minimum income } \\
\text { guarantee }\end{array}$ & & & & & & $\begin{array}{l}0.421^{* *} \\
(0.185) \\
\end{array}$ & \\
\hline Award criteria & & & & & & & $\begin{array}{c}-1.742^{* * *} \\
(0.418)\end{array}$ \\
\hline Number of obs. & 1267 & 1132 & 1226 & 1267 & 1267 & 1262 & 1267 \\
\hline \multirow{2}{*}{ Log Likelihood } & -263.16 & -173.83 & -247.31 & -255.67 & -241.05 & -260.53 & -243.44 \\
\hline & & \multicolumn{4}{|c|}{ Marginal effects (dy/dx) ${ }^{\mathrm{a}}$} & & \\
\hline $\begin{array}{l}\text { Existence of } \\
\text { regulatory body }\end{array}$ & -0.008 & -0.043 & -0.013 & -0.005 & 0.036 & -0.010 & -0.012 \\
\hline Price cap & 0.034 & & 0.016 & 0.011 & 0.010 & 0.027 & 0.016 \\
\hline Duration since award & 0.012 & 0.008 & 0.008 & 0.012 & 0.011 & 0.010 & 0.004 \\
\hline $\begin{array}{l}\text { Investment } \\
\text { requirements }\end{array}$ & 0.002 & -0.013 & 0.004 & 0.003 & -0.008 & 0.001 & -0.002 \\
\hline Bureaucratic quality & -0.040 & -0.0128 & -0.026 & -0.040 & -0.035 & -0.034 & -0.016 \\
\hline Election-1 & 0.043 & 0.006 & 0.048 & 0.036 & 0.025 & 0.046 & 0.024 \\
\hline GDP growth -1 & -0.005 & -0.002 & -0.005 & -0.005 & -0.005 & -0.005 & -0.003 \\
\hline GDP growth -2 & -0.002 & -0.001 & -0.002 & -0.002 & -0.001 & -0.002 & -0.002 \\
\hline $\begin{array}{l}\text { Transport sector } \\
\text { dummy }\end{array}$ & -0.115 & -0.006 & -0.017 & -0.096 & -0.228 & -0.137 & -0.018 \\
\hline Private financing & & -0.057 & & & & & \\
\hline Arbitration process & & & -0.084 & & & & \\
\hline Bidding process & & & & 0.039 & & & \\
\hline Corruption & & & & & 0.039 & & \\
\hline $\begin{array}{l}\text { Minimum income } \\
\text { guarantee }\end{array}$ & & & & & & 0.037 & \\
\hline Award criteria & & & & & & & -0.055 \\
\hline
\end{tabular}

Constant term omitted. Standard errors in parenthesis. Coefficients significant at the $1 \%\left({ }^{* * *}\right), 5 \%\left({ }^{* *}\right)$ and $10 \%\left(^{*}\right)$ level.

(a) For dummy variables, dy/dx is for discrete change from 0 to 1 . For continuous variables, it corresponds to an increase by 1 unit. 
Table 4: Instrumental variable estimations

(A)

Random effect probit

\begin{tabular}{|c|c|c|c|c|c|c|}
\hline & (1) & (2) & (3) & (4) & (5) & (6) \\
\hline Dependent variable & Gov-Reneg & Gov-Reneg & Gov-Reneg & Gov-Reneg & Gov-Reneg & Gov-Reneg \\
\hline $\begin{array}{l}\text { Existence of } \\
\text { regulatory body }\end{array}$ & $\begin{array}{c}0.035 \\
(0.262)\end{array}$ & $\begin{array}{l}-0.059 \\
(0.203)\end{array}$ & $\begin{array}{c}0.119 \\
(0.360)\end{array}$ & $\begin{array}{c}-0.735^{* * * *} \\
(0.274)\end{array}$ & $\begin{array}{l}-0.046 \\
(0.256)\end{array}$ & $\begin{array}{l}-0.132 \\
(0.212)\end{array}$ \\
\hline Price cap & & $\begin{array}{l}0.861^{* *} \\
(1.742)\end{array}$ & & & $\begin{array}{l}-0.600 \\
(2.755)\end{array}$ & $\begin{array}{l}0.745^{* *} \\
(2.006)\end{array}$ \\
\hline Price cap (IV) & $\begin{array}{c}2.187 * * * \\
(1.390)\end{array}$ & & $\begin{array}{l}2.594 * * * \\
(2.033)\end{array}$ & & & \\
\hline Duration since award & $\begin{array}{c}0.202^{* * * *} \\
(0.066)\end{array}$ & $\begin{array}{c}0.179 * * * \\
(0.044)\end{array}$ & $\begin{array}{c}0.255^{* * * *} \\
(0.084)\end{array}$ & $\begin{array}{c}0.143^{* * * *} \\
(0.047)\end{array}$ & $\begin{array}{c}0.257 * * * \\
(0.076)\end{array}$ & $\begin{array}{c}0.126 * * * \\
(0.045)\end{array}$ \\
\hline $\begin{array}{l}\text { Investment } \\
\text { requirements }\end{array}$ & $\begin{array}{l}-0.030 \\
(0.219)\end{array}$ & & & $\begin{array}{c}0.233 \\
(0.195)\end{array}$ & $\begin{array}{l}-0.087 \\
(0.194)\end{array}$ & $\begin{array}{c}0.004 \\
(0.158)\end{array}$ \\
\hline $\begin{array}{l}\text { Investment } \\
\text { Requirements (IV) }\end{array}$ & & $\begin{array}{c}-0.498^{* * * *} \\
(0.223)\end{array}$ & $\begin{array}{c}-0.702^{* * * *} \\
(0.270)\end{array}$ & & & \\
\hline Bureaucratic quality & $\begin{array}{c}-0.627 * * * \\
(0.231)\end{array}$ & $\begin{array}{c}-0.615^{* * *} \\
(0.148)\end{array}$ & $\begin{array}{c}-0.752 * * * \\
(0.259)\end{array}$ & $\begin{array}{c}-0.537 * * * \\
(0.180)\end{array}$ & $\begin{array}{c}-0.799 * * * \\
(0.250)\end{array}$ & $\begin{array}{c}-0.487 * * * \\
(0.142)\end{array}$ \\
\hline Private financing (IV) & & & & $\begin{array}{c}-2.068^{* * * *} \\
(0.487)\end{array}$ & & \\
\hline Bidding process (IV) & & & & & $\begin{array}{c}2.836 * * * \\
(4.513)\end{array}$ & \\
\hline $\begin{array}{l}\text { Minimum income } \\
\text { guarantee (IV) }\end{array}$ & & & & & & $\begin{array}{c}0.733 * * * \\
(0.265)\end{array}$ \\
\hline Election-1 & $\begin{array}{c}0.507 * * * \\
(0.130)\end{array}$ & $\begin{array}{c}0.481^{* * *} \\
(0.134)\end{array}$ & $\begin{array}{c}0.522^{* * *} \\
(0.141)\end{array}$ & $\begin{array}{c}0.541^{* * *} \\
(0.133)\end{array}$ & $\begin{array}{c}0.474 * * * \\
(0.135)\end{array}$ & $\begin{array}{c}0.559 * * * \\
(0.119)\end{array}$ \\
\hline GDP growth -1 & $\begin{array}{c}-0.080^{* * * *} \\
(0.032)\end{array}$ & $\begin{array}{c}-0.075^{* * * *} \\
(0.025)\end{array}$ & $\begin{array}{c}-0.095 * * * \\
(0.038)\end{array}$ & $\begin{array}{c}-0.086^{* * * *} \\
(0.022)\end{array}$ & $\begin{array}{c}-0.096 * * * \\
(0.036)\end{array}$ & $\begin{array}{c}-0.082^{* * * *} \\
(0.022)\end{array}$ \\
\hline GDP growth -2 & $\begin{array}{l}-0.027 \\
(0.040)\end{array}$ & $\begin{array}{l}-0.026 \\
(0.034)\end{array}$ & $\begin{array}{l}-0.032 \\
(0.046)\end{array}$ & $\begin{array}{l}-0.024 \\
(0.043)\end{array}$ & $\begin{array}{l}-0.028 \\
(0.047)\end{array}$ & $\begin{array}{l}-0.040 \\
(0.039)\end{array}$ \\
\hline $\begin{array}{l}\text { Transport sector } \\
\text { Dummy }\end{array}$ & $\begin{array}{c}-1.017^{* * * *} \\
(0.260)\end{array}$ & $\begin{array}{c}-0.773^{* * *} \\
(0.249)\end{array}$ & $\begin{array}{c}-0.864 * * * \\
(0.376)\end{array}$ & $\begin{array}{c}0.058 \\
(0.330)\end{array}$ & $\begin{array}{c}-0.860^{* * * *} \\
(0.281)\end{array}$ & $\begin{array}{c}-1.217^{* * * *} \\
(0.237)\end{array}$ \\
\hline Number of obs. & 1267 & 1267 & 1267 & 1267 & 1267 & 1267 \\
\hline Log Likelihood & -254.71 & -261.09 & -251.36 & -256.37 & -248.34 & -259.53 \\
\hline (B) & & & nal effects ( & & & \\
\hline Exist of regul body & 0.002 & -0.004 & 0.005 & -0.056 & -0.002 & -0.009 \\
\hline Price cap & 0.136 & 0.032 & 0.122 & & -0.044 & 0.029 \\
\hline Duration since award & 0.013 & 0.012 & 0.012 & 0.008 & 0.011 & 0.008 \\
\hline Invt requirements & -0.002 & -0.034 & -0.033 & 0.012 & -0.004 & 0.0003 \\
\hline Bureaucratic quality & -0.039 & -0.041 & -0.035 & -0.031 & -0.035 & -0.033 \\
\hline Private financing & & & & -0.120 & & \\
\hline Bidding process & & & & & 0.124 & \\
\hline Min income guarantee & & & & & & 0.049 \\
\hline Election-1 & 0.039 & 0.039 & 0.031 & 0.039 & 0.025 & 0.046 \\
\hline GDP growth -1 & -0.005 & -0.005 & -0.004 & -0.005 & -0.004 & -0.006 \\
\hline GDP growth -2 & -0.002 & -0.002 & -0.001 & -0.001 & -0.001 & -0.003 \\
\hline Transport dummy & -0.109 & -0.078 & -0.067 & 0.003 & -0.063 & -0.152 \\
\hline
\end{tabular}

(C) 2SLS

\begin{tabular}{|l|c|c|c|c|c|c|}
\hline Exist of regul body & $-0.014(0.020)$ & $-0.030(0.020)$ & $-0.018(0.021)$ & $-0.075^{* * *}(0.022)$ & $-0.021(0.020)$ & $-0.029(0.020)$ \\
\hline Price cap & $0.148^{* * *}(0.040)$ & $0.046^{*}(0.025)$ & $0.141^{* * *}(0.041)$ & & $-0.014(0.032)$ & $0.039(0.027)$ \\
\hline Duration since award & $0.014^{* * *}(0.004)$ & $0.014^{* * *}(0.004)$ & $0.015^{* * *}(0.004)$ & $0.020^{* * *}(0.004)$ & $0.015^{* * *}(0.004)$ & $0.013^{* * *}(0.004)$ \\
\hline Invt requirements & $0.013(0.022)$ & $-0.056(0.037)$ & $-0.060(0.038)$ & $-0.009(0.021)$ & $0.005(0.022)$ & $0.001(0.022)$ \\
\hline Bureaucratic quality & $-0.052^{* * *}(0.011)$ & $-0.054^{* * *}(0.011)$ & $-0.056^{* * *}(0.011)$ & $-0.016(0.012)$ & $-0.058^{* * *}(0.011)$ & $-0.044^{* * *}(0.012)$ \\
\hline Private financing & & & & $-0.138^{* * *}(0.048)$ & & \\
\hline Bidding process & & & & & $0.105^{* * *}(0.032)$ & \\
\hline Min income guarantee & & & & & & $0.040(0.029)$ \\
\hline Election-1 & $0.058^{* * *}(0.015)$ & $0.056^{* * *}(0.015)$ & $0.056^{* * *}(0.015)$ & $0.012(0.014)$ & $0.056^{* * *}(0.015)$ & $0.059^{* * *}(0.015)$ \\
\hline GDP growth -1 & $-0.006^{* * *}(0.002)$ & $-0.006^{* * *}(0.002)$ & $-0.006^{* * *}(0.002)$ & $-0.005^{* *}(0.002)$ & $-0.006^{* * *}(0.002)$ & $-0.006^{* * *}(0.002)$ \\
\hline GDP growth -2 & $-0.003(0.002)$ & $-0.003(0.002)$ & $-0.002(0.002)$ & $-0.002(0.002)$ & $-0.003(0.002)$ & $-0.003(0.002)$ \\
\hline Transport dummy & $-0.136^{* * *}(0.025)$ & $-0.097^{* * *}(0.030)$ & $\left.-0.098^{* * *} 0.031\right)$ & $-0.061^{*}(0.037)$ & $-0.120^{* * *}(0.025)$ & $-0.140^{* * *}(0.026)$ \\
\hline
\end{tabular}

Constant term omitted. Significance level: $1 \%(* * *), 5 \%(* *)$ and $10 \%(*)$.

Panel (A): Standard errors in parenthesis are bootstrapped estimates based on 100 replications. The significance level (1\%

(***), $5 \%\left({ }^{* *}\right)$ and $\left.10 \%(*)\right)$ is assessed using the percentile confidence interval. For example, for the $95 \%$ interval, the bottom endpoint is the $2.5^{\text {th }}$ percentile and the upper endpoint is the $97.5^{\text {th }}$ percentile. If the confidence interval build in that way contains 0 , the coefficient is deemed not significant. Non-normality of the distribution may explain that coefficients are found significant while having relatively large standard errors.

Panel (B): Values reported are marginal effects of second stage probit estimations. For dummy variables, dy/dx is for discrete change from 0 to 1 . For continuous variables, it corresponds to an increase by 1 unit.

Panel (C): 2SLS Linear probability model estimated using fitted values from the first stage probit as instruments (see Wooldridge (2002) pages 621-25. Standard errors in parenghgsis. 
Table 5: Random effect probit panel Additional results and robustness checks

\begin{tabular}{|c|c|c|c|c|c|}
\hline & $(1)$ & $(2)$ & (3) & $(4)$ & $(5)$ \\
\hline Dependent variable & $\begin{array}{l}\text { Reneg. } \\
\text { Initiated by } \\
\text { Govt }\end{array}$ & $\begin{array}{l}\text { Reneg. } \\
\text { Initiated by } \\
\text { Govt }\end{array}$ & $\begin{array}{l}\text { Reneg. } \\
\text { Initiated by } \\
\text { Govt }\end{array}$ & $\begin{array}{c}\text { Reneg. } \\
\text { Initiated by } \\
\text { Govt or both }\end{array}$ & $\begin{array}{c}\text { Reneg. } \\
\text { Initiated by } \\
\text { Govt or both }\end{array}$ \\
\hline $\begin{array}{l}\text { Existence of } \\
\text { regulatory body }\end{array}$ & $\begin{array}{c}-6.227 * * * \\
(1.334)\end{array}$ & $\begin{array}{c}1.108^{* * *} \\
(0.302)\end{array}$ & $\begin{array}{l}-0.144 \\
(0.202)\end{array}$ & $\begin{array}{c}0.034 \\
(0.181) \\
\end{array}$ & $\begin{array}{c}0.194 \\
(0.218) \\
\end{array}$ \\
\hline Price cap & $\begin{array}{l}-0.013 \\
(0.410)\end{array}$ & $\begin{array}{c}0.300 \\
(0.397)\end{array}$ & $\begin{array}{l}0.710^{* *} \\
(0.316)\end{array}$ & $\begin{array}{l}0.571^{* *} \\
(0.252)\end{array}$ & \\
\hline Price cap (IV) & & & & & $\begin{array}{l}1.891^{* *} \\
(0.721)\end{array}$ \\
\hline Duration since award & $\begin{array}{c}0.282 * * * \\
(0.048)\end{array}$ & $\begin{array}{c}0.276^{* * *} \\
(0.046)\end{array}$ & $\begin{array}{c}0.154^{* * *} \\
(0.038)\end{array}$ & $\begin{array}{c}0.136 * * * \\
(0.034)\end{array}$ & $\begin{array}{c}0.181^{* * *} \\
(0.049)\end{array}$ \\
\hline $\begin{array}{l}\text { Investment } \\
\text { requirements }\end{array}$ & $\begin{array}{l}-0.330^{*} \\
(0.187) \\
\end{array}$ & $\begin{array}{c}-0.200 \\
(0.177) \\
\end{array}$ & $\begin{array}{c}0.092 \\
(0.170) \\
\end{array}$ & $\begin{array}{c}0.068 \\
(0.159) \\
\end{array}$ & \\
\hline $\begin{array}{l}\text { Investment } \\
\text { Requirements (IV) }\end{array}$ & & & & & $\begin{array}{c}-0.515^{* *} \\
(0.237)\end{array}$ \\
\hline Bureaucratic quality & $\begin{array}{c}-1.017 * * * \\
(0.155)\end{array}$ & $\begin{array}{c}-0.912 * * * \\
(0.148)\end{array}$ & $\begin{array}{c}-0.324 * * \\
(0.133)\end{array}$ & $\begin{array}{c}-0.519 * * * \\
(0.102)\end{array}$ & $\begin{array}{c}-0.666^{* * *} \\
(0.154)\end{array}$ \\
\hline Corruption & $\begin{array}{l}-0.956 * * * \\
(0.355)\end{array}$ & $\begin{array}{l}1.443^{* * *} \\
(0.292)\end{array}$ & & & \\
\hline Regulator * Corruption & $\begin{array}{c}2.281 * * * \\
(0.441)\end{array}$ & & & & \\
\hline Election-1 $*$ Corruption & & $\begin{array}{c}-0.714^{* *} \\
(0.289) \\
\end{array}$ & & & \\
\hline Election-1 * Bur. quality & & & $\begin{array}{c}-0.645^{* * *} \\
(0.247)\end{array}$ & & \\
\hline Election-1 & $\begin{array}{c}0.556 * * * \\
(0.138)\end{array}$ & $\begin{array}{c}2.595 * * * \\
(0.870)\end{array}$ & $\begin{array}{l}2.590 * * * \\
(0.808)\end{array}$ & $\begin{array}{c}0.515^{* * *} \\
(0.114)\end{array}$ & $\begin{array}{c}0.511 * * * \\
(0.135)\end{array}$ \\
\hline GDP growth -1 & $\begin{array}{c}-0.156^{* * *} \\
(0.024)\end{array}$ & $\begin{array}{c}-0.126^{* * *} \\
(0.022)\end{array}$ & $\begin{array}{c}-0.063^{* * *} \\
(0.018)\end{array}$ & $\begin{array}{c}-0.043^{* * *} \\
(0.016)\end{array}$ & $\begin{array}{c}-0.057 * * \\
(0.027) \\
\end{array}$ \\
\hline GDP growth -2 & $\begin{array}{c}-0.071^{* *} \\
(0.031) \\
\end{array}$ & $\begin{array}{l}-0.032 \\
(0.029) \\
\end{array}$ & $\begin{array}{l}-0.014 \\
(0.025) \\
\end{array}$ & $\begin{array}{l}-0.019 \\
(0.023) \\
\end{array}$ & $\begin{array}{l}-0.016 \\
(0.036) \\
\end{array}$ \\
\hline $\begin{array}{l}\text { Transport sector } \\
\text { Dummy }\end{array}$ & $\begin{array}{c}-1.340^{* * *} \\
(0.303)\end{array}$ & $\begin{array}{c}-1.922 * * * \\
(0.305)\end{array}$ & $\begin{array}{c}-0.952 * * * \\
(0.224)\end{array}$ & $\begin{array}{c}-0.859 * * * \\
(0.202)\end{array}$ & $\begin{array}{c}-0.651^{* * *} \\
(0.240)\end{array}$ \\
\hline Number of obs. & 1267 & 1267 & 1267 & 1267 & 1267 \\
\hline Log Likelihood & -227.38 & -237.37 & -259.26 & -309.80 & -298.77 \\
\hline \multicolumn{6}{|c|}{ Marginal effects (dy/dx)a } \\
\hline $\begin{array}{l}\text { Existence of regulatory } \\
\text { body }\end{array}$ & -0.955 & 0.028 & -0.011 & 0.004 & 0.017 \\
\hline Price cap & -0.000 & 0.007 & 0.032 & 0.042 & 0.174 \\
\hline Duration since award & 0.007 & 0.008 & 0.011 & 0.014 & 0.017 \\
\hline Investment requirements & -0.010 & -0.007 & 0.006 & 0.007 & -0.047 \\
\hline Bureaucratic quality & -0.024 & -0.028 & -0.024 & -0.055 & -0.061 \\
\hline Corruption & -0.023 & 0.044 & & & \\
\hline Regulator * Corruption & 0.054 & & & & \\
\hline Election-1 $*$ Corruption & & -0.022 & & & \\
\hline Election-1 * Bur. quality & & & -0.047 & & \\
\hline Election-1 & 0.018 & 0.309 & 0.468 & 0.064 & 0.056 \\
\hline GDP growth -1 & -0.004 & -0.004 & -0.005 & -0.005 & -0.005 \\
\hline GDP growth -2 & -0.002 & -0.001 & -0.001 & -0.002 & -0.001 \\
\hline Transport sector Dummy & -0.084 & -0.205 & -.113 & -0.131 & -0.080 \\
\hline
\end{tabular}

Constant term omitted. Standard errors in parenthesis Standard errors in column 5 are bootstrapped estimates based on 100 replications. The significance level $(1 \%(* * *), 5 \%(* *)$ and $10 \%(*))$ is assessed using the percentile confidence interval. For example, for the $95 \%$ interval, the bottom endpoint is the $2.5^{\text {th }}$ percentile and the upper endpoint is the $97.5^{\text {th }}$ percentile. If the confidence interval build in that way contains 0 , the coefficient is deemed not significant. Non-normality of the distribution may explain that coefficients are found significant while having relatively large standard errors.

(a) For dummy variables, dy/dx is for discrete change from 0 to 1 . For continuous variables, it corresponds to an increase by 1 unit. 